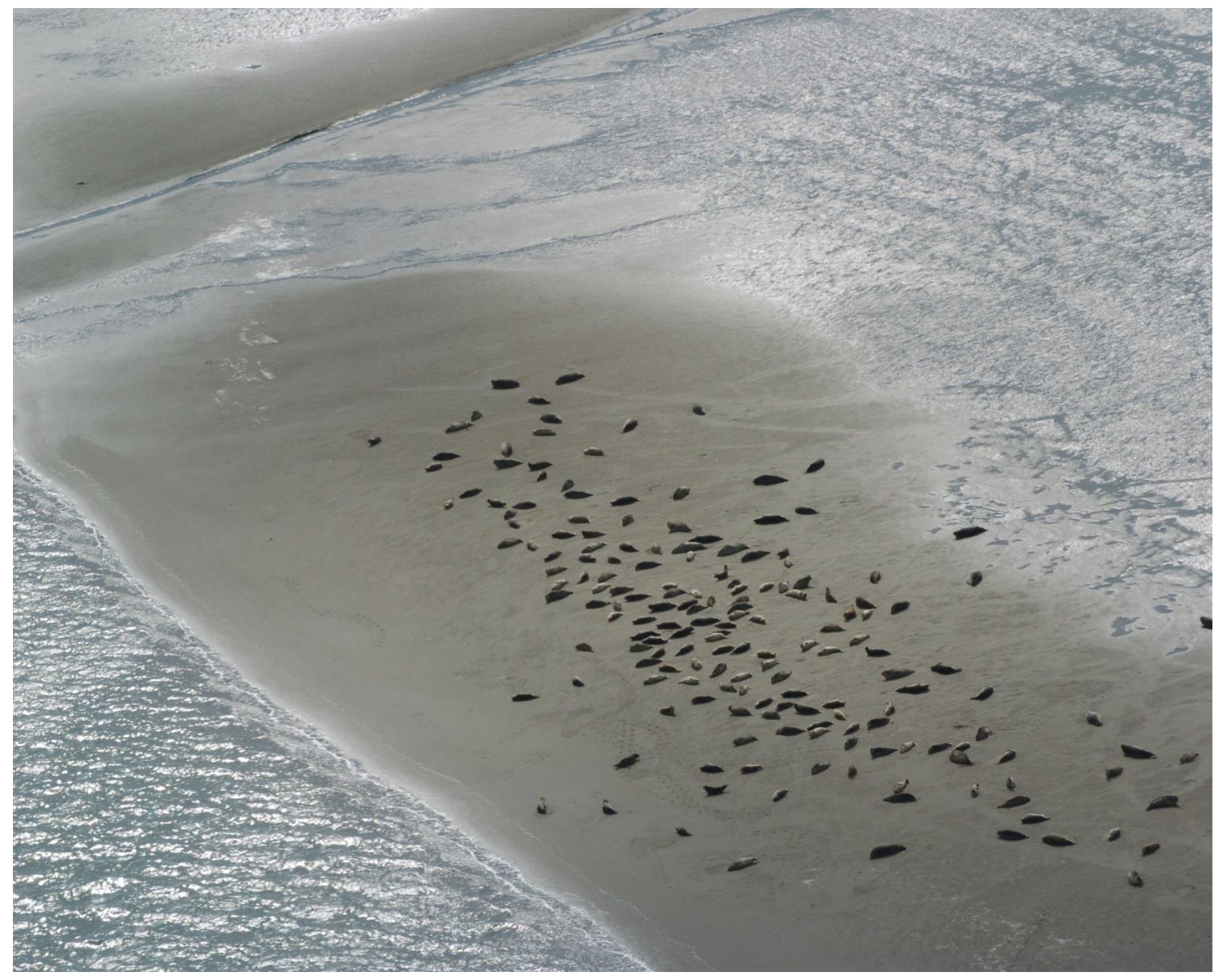

\title{
Spatial distribution and habitat preference of harbour seals (Phoca vitulina) in the Dutch North Sea
}

Authors: Geert Aarts, Jenny Cremer, Roger Kirkwood, Jan Tjalling van der Wal, Jason Matthiopoulos ${ }^{1} \&$ Sophie Brasseur

${ }^{1}=$ Glasgow University
Wageningen University \&

Research Report C118/16 


\section{Spatial distribution and habitat preference of harbour seals (Phoca vitulina) in the Dutch North Sea}

Author(s): $\quad$ Geert Aarts, Jenny Cremer, Roger Kirkwood, Jan Tjalling van der Wal, Jason Matthiopoulos ${ }^{1} \&$ Sophie Brasseur

${ }^{1}=$ Glasgow University

Publication date: $8^{\text {th }}$ December 2016 
Geert Aarts, Jenny Cremer, Roger Kirkwood, Jan Tjalling van der Wal, Jason Matthiopoulos ${ }^{1}$ \& Sophie Brasseur, 2016. Spatial distribution and habitat preference of harbour seals (Phoca vitulina) in the Dutch North Sea. Wageningen University \& Research centre, Wageningen Marine Research, Wageningen Marine Research report number C118/16, 43 pageshttp://dx.doi.org/10.18174/400306

${ }^{1}=$ Glasgow University

Keywords: Species distribution, spatial modelling, animal-borne GPS tracking, aerial survey

Client: $\quad$ Rijkswaterstaat (Aylin Erkman)

Verkenning en Planuitwerking

Rijkswaterstaat Zee en Delta

Poelendaelesingel 18

4335 JA Middelburg

Wageningen Marine Research is ISO 9001:2008 certified.

This report can be downloaded for free from http://dx.doi.org/10.18174/400306.

Wageningen Marine Research does not provide hard copies of reports

Photo cover: Sophie Brasseur

(C) 2016 Wageningen Marine Research Wageningen UR

Wageningen Marine Research The Management of Wageningen Marine Research is not responsible for resulting institute of Stichting Wageningen damage, as well as for damage resulting from the application of results or Research is registered in the Dutch research obtained by Wageningen Marine Research, its clients or any claims traderecord nr. 09098104, related to the application of information found within its research. This report BTW nr. NL 806511618 has been made on the request of the client and is wholly the client's property. This report may not be reproduced and/or published partially or in its entirety without the express written consent of the client. 


\section{Contents}

$\begin{array}{lr}\text { Summary } & 4\end{array}$

$1 \quad$ Introduction $\quad 5$

2 Methods $\quad 7$

$2.1 \quad$ Harbour seal GPS tracking $\quad 7$

$\begin{array}{lll}2.2 & \text { Aerial survey haul-out counts } & 7\end{array}$

$\begin{array}{ll}2.3 \text { Telemetry data pre-processing and trip definition } & 8\end{array}$

2.4 Explanatory variables used for habitat modelling $\quad 8$

2.4.1 Distance to haul-out $\quad 8$

2.4.2 Sediment 9

$\begin{array}{ll}2.4 .3 & \text { Depth }\end{array}$

2.5 Habitat modelling $\quad 11$

2.6 Model fitting and parameter estimation 12

$\begin{array}{lll}2.7 & \text { Spatial predictions of population abundance } & 13\end{array}$

$3 \quad$ Results $\quad 15$

3.1 Harbour seal tracking $\quad 15$

3.2 Distribution and abundance of seals on the haul-out sites 16

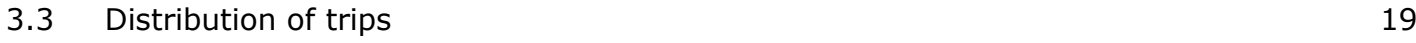

$\begin{array}{lll}3.4 & \text { Preference for environmental variables } & 20\end{array}$

3.5 Predicted Spatial distribution $\quad 22$

$\begin{array}{llr}4 & \text { Discussion } & \mathbf{2 7}\end{array}$

4.1 Distribution and habitat selection of harbour seals in the Dutch waters 27

4.2 The importance of accurate land-based survey data to estimate at-sea distribution 27

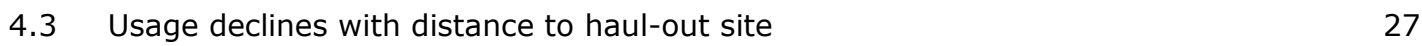

$\begin{array}{ll}4.4 & \text { Seasonal variability in their distribution at-sea }\end{array}$

4.5 From species density towards cumulative usage $\quad 29$

$\begin{array}{lll}4.6 & \text { Limitations } & 30\end{array}$

$\begin{array}{lll}4.7 & \text { Future changes in distribution? } & 31\end{array}$

$5 \quad$ Acknowledgements $\quad 32$

$\begin{array}{llr}6 & \text { Literature cited } & 33\end{array}$

$7 \quad$ Quality Assurance $\quad 36$

$\begin{array}{lr}\text { Justification } & 37\end{array}$

$\begin{array}{lll}\text { Annex } 1 & \text { Seasonal distribution of seal GPS locations } & 38\end{array}$ 


\section{Summary}

Management of the marine environment and conservation of the species that live within it requires accurate information on where animals are, why they are there, and where else they could have been. The harbour seal Phoca vitulina is a widely distributed marine mammal, found in coastal waters of the northern Pacific and Atlantic Oceans, and including the Baltic and North Sea. Data from over 200 GPS tracked harbour seals were used to estimate their distribution at sea in relation to environmental conditions. The model results were supplemented with data from aerial surveys of seals hauled-out on land, to estimate expected density of seals at sea. Seal density was found to be substantially high near haul-out sites and areas of $\sim 30 \mathrm{~m}$ water depth, with low mud content. Harbour seals venture further away from the haul-out sites during the winter months (Dec. - Feb.). This seasonal pattern is also supported by independent coastal observations from the Dutch west coast. In addition to their longer trips, seals spend substantially less time on land $(\sim 10 \%)$ during the winter compared to the spring and summer ( $>20 \%$ ). This shift is driven by water temperature, changed prey redistribution, increased requirements of the seals or a combination of these factors. This study shows how the distribution at sea of a population of seals can be estimated by combining detailed individual movement data and data from population counts on land. The model can subsequently be used to study if residual variations in seal densities can be explained by human activities at sea. Furthermore, the model predictions can be used as input variables for individual-based models aimed at estimating the population-level impact of human activities on harbour seals. 


\section{Introduction}

The increasing anthropogenic use of the marine environment may impact several resident species. The spatial overlap between human activities and the distribution of a species, largely determines the size of the impact. Thus, to assess the impact of human activities on each species it is first necessary to know where and when individuals occur and to understand the underlying drivers of why. Estimating the spatial distribution of most marine species, particularly marine mammals, can be challenging, partly due to their elusive nature (Myers \& Bowen 1989; Härkönen, Harding \& Lunneryd 1999; Hammond et al. 2002), but also due to the higher cost of sampling in the marine environment. Fortunately, recent decades have seen rapid development in wildlife tracking devices, providing detailed information on individual movement into remote areas (Siniff et al. 1975; McConnell, Chambers \& Fedak 1991; Thompson et al. 1996; Cronin \& McConnell 2008; Costa et al. 2010; Dujon, Lindstrom \& Hays 2014). Although valuable, animal movement data often reveal large individual variability in space-use (Austin, Bowen \& McMillan 2004; Sharples, Mackenzie \& Hammond 2009; Cronin et al. 2010; Zanden et al. 2010; Sharples et al. 2012; Cordes \& Thompson 2015) and tagging efforts tend to be concentrated in specific regions, hence biasing distribution estimates for the entire population.

An alternative approach to estimate the distribution of a species based on tracking data, is to quantify which habitats are preferentially selected, and subsequently use this information for spatial prediction. This idea has led to the development of a large variety of habitat selection models, many of which have been fitted to individual tracking data (Aarts et al. 2008). However, to correct for imbalances in spatial tagging effort, independent population survey data are needed to estimate population-level densities at sea. In this study, we use habitat selection models fitted to individual tracking data from harbour seals (Phoca vitulina), and rescale the predictions to absolute abundance density using independent aerial survey counts of seals on-land.

The harbour seal is the most abundant seal species of the Wadden Sea (bordering the Netherlands, Germany and Denmark). Approximately 39,000 harbour seals are estimated to be present in the Wadden Sea, 27\% of which in Dutch waters (Galatius et al. 2015). Harbour seals haul-out on sandbanks or edges of intertidal flats. During the pupping (June-July) and moult (July-September) seasons, a consistent proportion of the population is found on land. Hence most surveys assessing population size and pup production are carried out during these periods (Thompson et al. 1997; Meesters et al. 2007; Teilmann, Rigét \& Harkonen 2010; Cowles et al. 2013). However, harbour seals also utilise haul-out sites throughout the year, presumably to rest.

From the haul-out sites, harbour seals undertake regular trips to sea, mostly to feed. Harbour seals mostly feed near the bottom on a variety of relatively small prey species (i.e. $10-16 \mathrm{~cm}$, Tollit, Thompson \& Greenstreet (1997)), e.g. flounder, plaice, sole, sandeel, dragonet (unpublished data from Dutch diet studies). Although harbour seals can make trips of tens to hundreds of kilometres, they mostly forage within $50 \mathrm{~km}$ from their haul-out site in the North Sea, in relatively shallow waters (10-50m) characterized by sandy substrates (Tollit et al. 1998; Sharples et al. 2012; Bailey, Hammond \& Thompson 2014; Jones et al. 2015).

The objective of this study was to describe the harbour seals' distribution at sea, quantify their selection for certain areas at sea, given the local environmental conditions, and use this habitat model to predict the distribution at sea of all harbour seals hauling-out in the Netherlands. This was achieved by developing a habitat selection model using tracking data from 219 harbour seals and combining 
these with information on the number of seals at the haul-out sites. This study provides the first concise at-sea distribution estimate of all harbour seals using haul-out sites located in Dutch waters. 


\section{Methods}

\subsection{Harbour seal GPS tracking}

This study relied on existing data from animal-borne GPS data loggers collected in other research projects (Brasseur et al. 2009a; b, 2010, 2011; Kirkwood, Bos \& Brasseur 2014; Brasseur \& Kirkwood 2015; Kirkwood, Aarts \& Brasseur 2015). Between 2007 and 2015 a total of 225 harbour seals were fitted with tracking devices. The vast majority of tagged animals (i.e. 142 individuals) were from the Ems estuary, tagged between 2009 and 2011. Most seals were tagged in March $(\mathrm{N}=123)$ and September $(\mathrm{N}=91)$, and most location data were collected during the first months following tagging. In summary, harbour seals were caught on the haul-out site with a large seine net, and tagged and released directly on location within 1:30 hour after capture. GPS data loggers were glued to the fur of the back, central and just behind the neck, using quick-setting epoxy. Because the data loggers are glued to the seals' fur, they fall off when the fur is shed during the annual moult. The moult may start as early as late spring, causing tags to fall off somewhere between May and July. By September, most harbour seals have completely moulted.

The Fastloc GPS data loggers (Sea Mammal Research Unit, UK) were set to collect and store GPS locations every 10-20 min (depending on the research project). Data from a depth sensor (precision of $0.5 \mathrm{~m}$ ) and a submergence sensor were used to determine the activity of the seal: "diving" (deeper than $1 \mathrm{~m}$ for at least $4 \mathrm{~s}$ ), "at surface" (no dives for $180 \mathrm{~s}$ ) or "hauled out" (continuously dry for at least $600 \mathrm{~s}$ until wet for $40 \mathrm{~s}$ ). Dive records included maximum dive depth, dive duration, and surface interval duration. In this study, we used the two-hourly summary records, including the percentages of time spent diving, time spent at the surface, and time spent at the haul-out. Locations, dive, haulout, and summary records were stored and the Fastloc GPS data loggers transmitted the data via GSM, when in contact with a GSM base.

\subsection{Aerial survey haul-out counts}

In the Dutch Wadden Sea, multiple aerial counts were carried out annually for grey and harbour seals) (Reijnders 1978; Reijnders et al. 1997; Meesters et al. 2007). For both species, a minimum of 5 aerial surveys were carried out each year, 3 during pupping periods (Jun. - Jul. for the harbour seal; Nov. Jan. for grey seals) and 2 during moulting period (Aug. for the harbour seal; Mar. - Apr. for grey seals). The flight tracks were chosen to cover all known haul-out sites for the targeted seal species, which do not always overlap. Due to this difference in use of haul-out sites and limited daylight, not all harbour seal haul-out sites were visited in winter (grey seal pupping period) and spring (grey seal moult period), particularly those further south into the Wadden Sea. In order for this study to estimate the distribution of harbour seals outside the moulting and pupping seasons, on 18 April 2016 (during the grey seal moult), a more comprehensive survey was undertaken, covering all known harbour seal haul-out sites.

Aerial surveys were carried out from a fixed-wing, single engine aircraft, flying at approximately $500 \mathrm{ft}$ $(\sim 150 \mathrm{~m})$ and 150-200 km/h. Surveys were conducted within a 4-h window between 2-h before and 2-h after low tide and were aimed at low tides between 1200 and 1600 (Reijnders et al. 2003). Surveys were performed on good weather days, with daily rainfall $<8.5 \mathrm{~mm}$ (measured from 0800 UTC the preceding day), winds below $46 \mathrm{~km} / \mathrm{h}$ ( 25 knots, or 6 Beaufort), and good visibility. The flight route was recorded using GPS. From 2000 onwards, a digital camera was used to register the number 
of seals present at the haul-out sites. In the laboratory, these images were projected on screen, and all animals were counted, separating species and, when applicable, pups from adults.

\subsection{Telemetry data pre-processing and trip definition}

First, records of unrealistically long haul-out durations with no subsequent trip to sea, presumably caused by tags falling off on land (mostly during the moult), were removed from the analysis. Because seals may behave different just after the tagging event, data from seals with less than 10 days of data were removed. To predict absolute densities at sea for the entire population based on aerial survey haul-out counts, it was necessary to model the spatial distribution of tracked seals relative to the haulout sites from which they performed trips and, for this, each trip to sea was linked to the corresponding start and end haul-out. The GPS data loggers record the start and end of each haul-out event (i.e. continuously dry for at least $600 \mathrm{~s}$ ). The location of that haul-out event was estimated as the average location of all GPS-fixes during that event. If no location estimate was obtained during the actual haul-out event, the location closest in time before or after the haul-out event was used (up to a maximum of 1 hour). Each recorded haul-out location was subsequently linked to the nearest known haul-out site recorded during the aerial surveys. For transitory trips (i.e. different start and end haulout site), all locations prior to the midpoint (in time) of the trip were allocated to the start haul-out, and those after the midpoint to the end haul-out.

\subsection{Explanatory variables used for habitat modelling}

Seals are central-place foragers, feeding predominantly near the bottom on benthic prey species. Other studies have shown that harbour seals use areas that are relatively shallow and characterized by sandy substrate (Tollit et al. 1998; Sharples et al. 2012; Bailey, Hammond \& Thompson 2014; Jones et al. 2015). For that reason the covariates, distance to haul-out, depth and sediment type (\%mud) were used. Also covariates on prey distribution could potentially be used. However, both the spatial and temporal resolution is often insufficient to capture the fine scale variations in seal density, and hence were not used in this study.

\subsubsection{Distance to haul-out}

Harbour seals are central-place foragers, and areas nearby their haul-out sites are therefore more easily accessible. Even if they select areas far away from the haul-out to forage, they always have to cross the intermediate areas. Consequently, habitat use is expected to be negatively correlated with distance to the haul-out site (Fig. 1). Because seals generally circumvent large sections of land or shallow areas, an R function was written to calculate at-sea distance (Aarts et al. 2008). This estimation was based on a regular 1 by $1 \mathrm{~km}$ grid created for the North Sea, each cell representing land or sea. The distance to haul-out site was calculated for each of the 1953 known haul-out sites in the Netherlands, Belgium, Germany, Denmark and UK. Most of these haul-out sites were derived from aerial surveys (Fig. 1a) and, where necessary, supplemented using data on haul-out events of the tracked seals (Fig. 1b). 


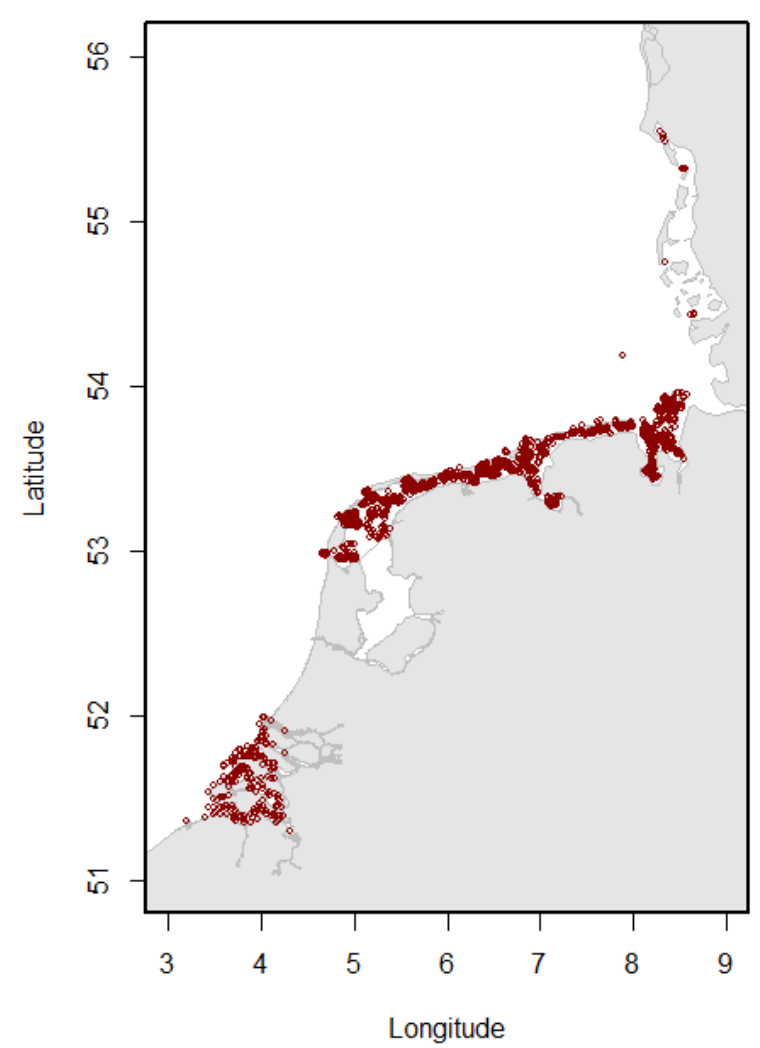

a. Distribution of all known haul-out sites

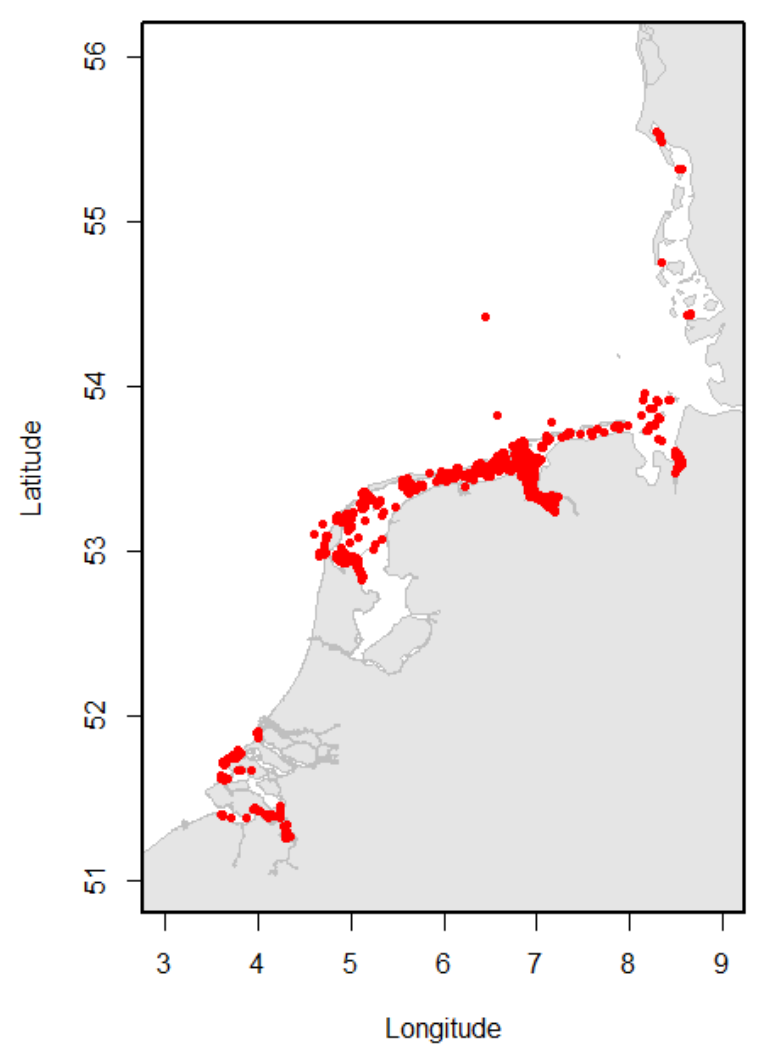

b. Distribution of haul-out events based on the tracked harbour seals (note that several events in open water likely resulted from seals remaining at the surface for $>10 \mathrm{~min}$., and were not recognised as haul-outs)

Fig. 1. Known haul-out sites in the Netherlands and Lower Saxony (Germany) based on aerial surveys (a), if necessary, supplemented with haul-out sites which were derived from the GPS data loggers (b).

\subsubsection{Sediment}

Sediment data was obtained from a combination of data collected in Dutch and German waters. In this study, we used \% mud (Fig. 2a, b). For the Dutch EEZ data, details can be found at http://www.emodnet-seabedhabitats.eu/pdf/Imares_Dutch_Marine_landscape_Map.pdf. For the German EEZ, an irregular point dataset data on the \%mud (and also sand\% and gravel\%) was provided by the German Bundesamt für Seeschiffahrt und Hydrographie (BSH). To achieve full coverage, the point data were interpolated using Ordinary Kriging with a spherical semi-variogram model (lag=0.039305) and a variable search radius aiming for 12 neighbouring points within a maximum distance of 0.2 degrees Lat/Lon. 


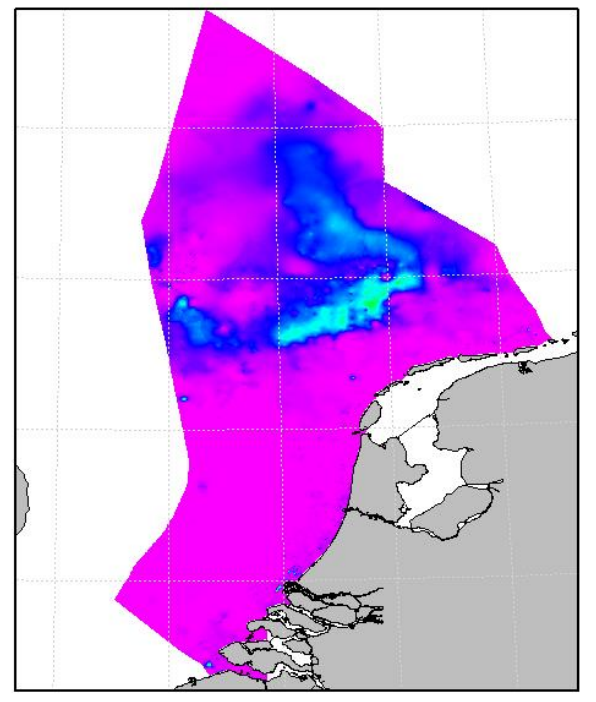

a. \% Mud on Dutch continental plate

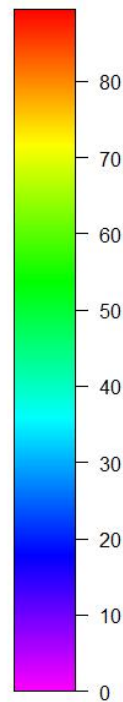

b. \% Mud on German continental plate

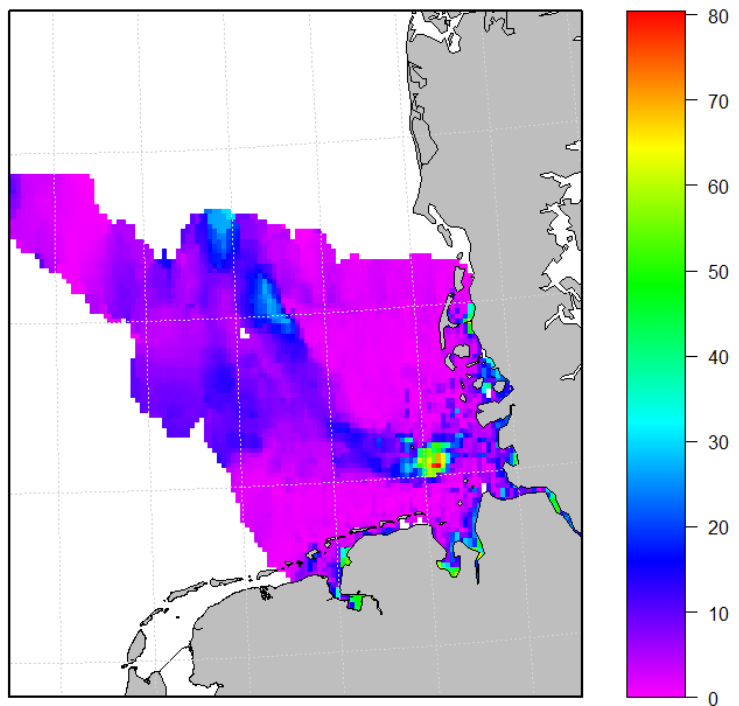

(a) and Germany (b).

\subsubsection{Depth}

Bathymetry data were extracted from the harmonized EMODnet Digital Terrain Model (DTM, see http://www.emodnet-hydrography.eu/), which is based on regional DTMs, and gaps with no data coverage were completed by integrating the GEBCO Digital Bathymetry (Fig. 3) 


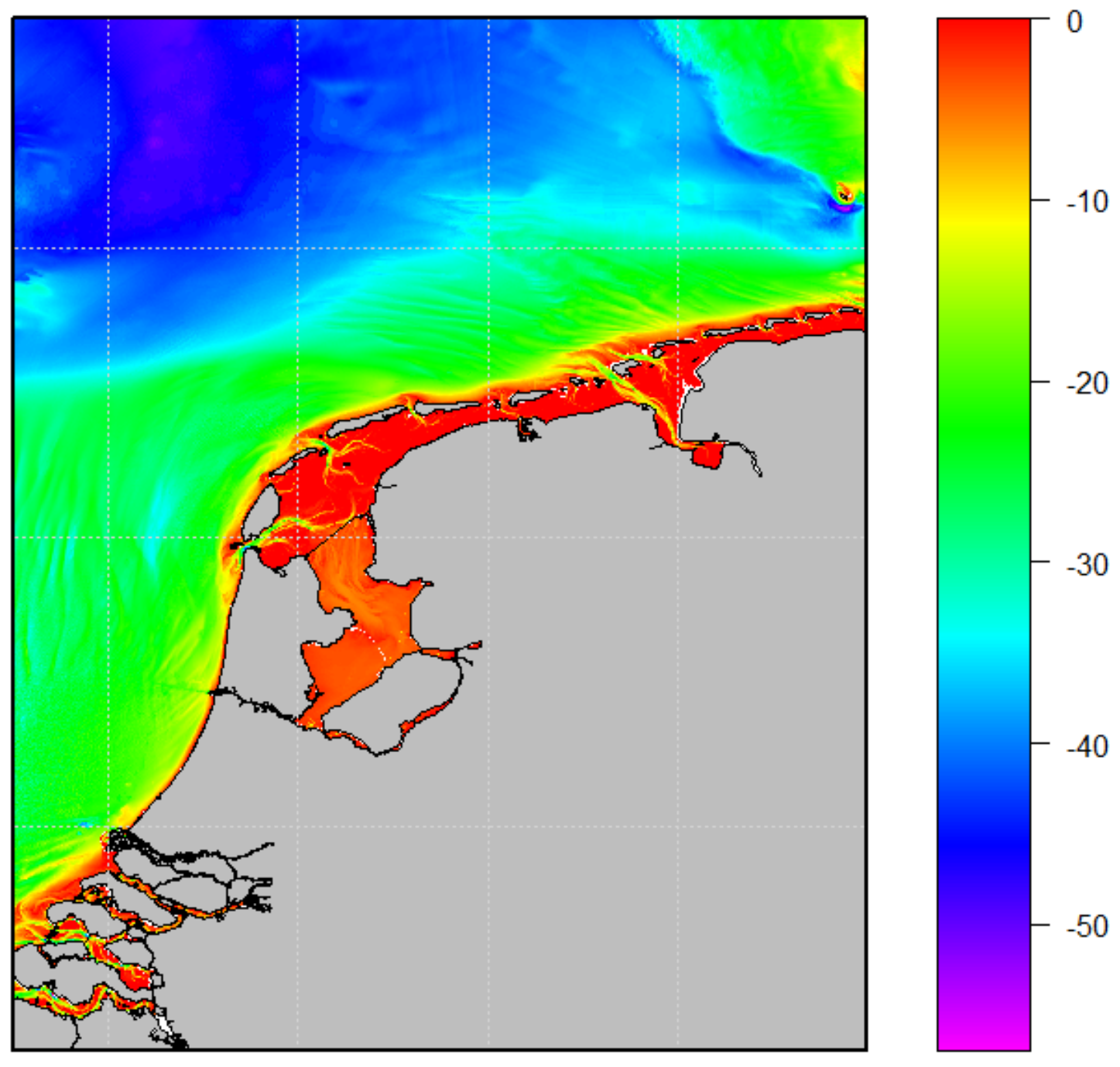

Fig. 3 Bathymetry (source: harmonized EMODnet Digital Terrain Model, http://www.emodnethydrography.eu/).

\subsection{Habitat modelling}

The spatial distribution of the observed animal locations in geographical space can be treated as realization of an inhomogeneous Poisson point process (IPP) with a rate $w(X)$. This rate $w(X)$ describes the animals' preference for being at a point in space with environmental conditions $X$. In accordance with count models, we assume that $w$ is the exponent of the linear predictor $\eta$

$$
w=e^{\eta}
$$

The simplest form of the linear predictor is to assume that it is a linear function of the environmental variables $x_{1}-x_{J}$. However, animals often respond non-linearly to environmental variables, e.g. they might have a peak preference for a particular explanatory variable. This non-linearity was included in the model by including smooth functions of $x$

$$
\eta=\beta_{0}+s\left(x_{1}\right) \cdots+s\left(x_{j}\right) \cdots+s\left(x_{J}\right)
$$


Here, b-spline smoothers consist of five basis functions, each being a different cubic polynomial of the original explanatory variable $x_{j}$ (function bs() within the R library 'splines') (Ramsay \& Silverman 2005).

$$
s\left(x_{j}\right)=\sum_{k=1}^{K} b_{k} f_{k}\left(x_{j}\right)
$$

where $f_{k}$ is the $k$ th basis function.

The wildlife telemetry locations come from different individuals that may differ in their preference for environmental conditions. To capture the hierarchical structure in the data (animal location, individual, (sub-)population) and to capture the non-independence in the observations within an individual, we used mixed-effect models. Each parameter $b$ in eq. 4 is treated as a normally distributed random variable (Pinheiro \& Bates 2000)

$$
b_{j, m}=\beta_{j, 0}+v_{j}
$$

where $m$ refers to the $m$ th individual and $v_{j}$ are the random effects which are assumed to have a joint multivariate normal distribution with a mean of zero and a variance-covariance matrix $\Psi$, representing within-class variability (Pinheiro and Bates 2000). Defining the coefficients of the basisfunctions of the b-spline smoothers as random effects, allows one to estimate if the functional form of this relationship differs between individuals.

\subsection{Model fitting and parameter estimation}

The habitat selection model can be fitted using the Conditional IPP likelihood function

$$
l_{C I P P}(\beta ; X)=\sum_{m=1}^{M} \sum_{k=1}^{K_{m}}\left\{\log \left(w\left(X_{k}^{U}\right)\right)-\log \left(\int_{S \in A} w\left(X_{S}\right) d S\right)\right\}
$$

Here, $M$ is the total number of unique seals, and $K_{m}$ is the total number of locations of the $m$ 'th seal. The integral represents what is available to each animal and is evaluated for each seal location, and is conditional on the haul-out to which the $m$ 'th location belongs. This integral is approximated by sampling points from geographical space and evaluation $w\left(X_{S}\right)$ for those "availability points".

$$
l_{C I P P}(\beta ; X)=\sum_{m=1}^{M} \sum_{k=1}^{K_{m}}\left\{\log \left(w\left(X_{k}^{U}\right)\right)-\log \left(\sum_{n=1}^{N_{k}} w\left(X_{n}\right)\right)\right\}
$$

The likelihood function (eq. 7) can be approximated using an infinite-weighted logistic regression, where each control observation received a large weight (i.e. 1000 in this study). As such, the model can be fitted using a standard logistic (mixed-effect) model.

In total, there were over 700,000 seal locations, and approximately 1.8 million availability points. Fitting a mixed-model with smooth terms would be computationally infeasible. To reduce the data, we chose to group observations with similar environmental values, using $k$-means clustering. All used and 
available points were pooled and clustered based on the environmental conditions at these points ( $R$ function 'kmeans'). The means of the environmental variables of each $c$ 'th cluster were used as covariate values (i.e. $X_{c}^{U}$ ), and the number of seal or availability locations included as model weight:

$$
l_{C I P P}(\beta ; X)=\sum_{m=1}^{M} \sum_{c=1}^{C_{m}}\left\{v_{c}^{U} \log \left(w\left(X_{c}^{U}\right)\right)-\log \left(\sum_{c=1}^{C_{m, k}} v_{c}^{A} w\left(X_{c}^{A}\right)\right)\right\}
$$

If each unique combination of environmental values would be presented by a single cluster, the likelihood in eq. 8 would be identical to eq. 7. However, reducing clusters could lead to (some) information loss. To examine at what number of clusters the information loss would be negligible, the number of clusters was increased until the estimated selection functions stabilized.

Variable selection was carried out using forward model-selection and likelihood-based cross validation. We treated data from seals tagged in each fieldwork session (i.e. a capture event on the same day and location) as an independent sample. A model was fitted using all telemetry data, except data from one capture event. Next, the model was used to predict the response data for the hold-out data and the likelihood was calculated. This was repeated for all capture events and the log-likelihood was summed.

\subsection{Spatial predictions of population abundance}

The habitat model describes the spatial variation in density as a function of the environmental covariates, conditional on an individual using a particular colony as its central place. This model can be used to predict the absolute seal density at sea $\gamma\left(X_{S}\right)$, by summing habitat use from all haul-out sites:

$$
\gamma\left(X_{S}\right)=\sum_{h=1}^{H}\left((1-\alpha) n_{h} \frac{N}{\sum_{h=1}^{H} n_{h}} \frac{w\left(X_{h, S}\right)}{\int_{S \in A} w\left(X_{h, S}\right) d S}\right)
$$

In eq. $9, w\left(X_{h, S}\right)$ is the relative density at a point in space $S$, as predicted by the habitat model for the $h$ 'th haul-out. The haul-out specific predictions were standardized such that the sum of the predictions over all points in space equalled 1 (i.e. $\int_{S \in A} w\left(X_{h, S}\right) d S=1$ ). These predictions were subsequently multiplied by the average number of seals using the haul-out (either to rest or as central-place to perform trips), which was estimated as the number of seals observed at haul-out $h$ during the survey (i.e. $n_{h}$ ), multiplied by the ratio of the total population size $N$ over the total number of seals observed on all $H$ haul-out sites during that particular survey (i.e. $\sum_{h=1}^{H} n_{h}$ ). Finally, on average, a fraction of $a$ seals are on land, the remaining fraction (1- $a$ ) can be found at sea. The monthly haul-out fractions, $a$ 's, were based on the data logger summary records, which provide 2- 
hourly estimates of the percentage haul-out, at-surface and diving. Using the data from all seals, the mean haul-out percentage was calculated for each month. 


\section{$3 \quad$ Results}

\subsection{Harbour seal tracking}

Of the 225 harbour seals tagged, 219 contained sufficient data ( $>10$ days) to be used in the analysis. Fig. 4 shows the at-sea locations recorded for all harbour seals tracked for $>10 \mathrm{~d}$ between 2007 and 2015.

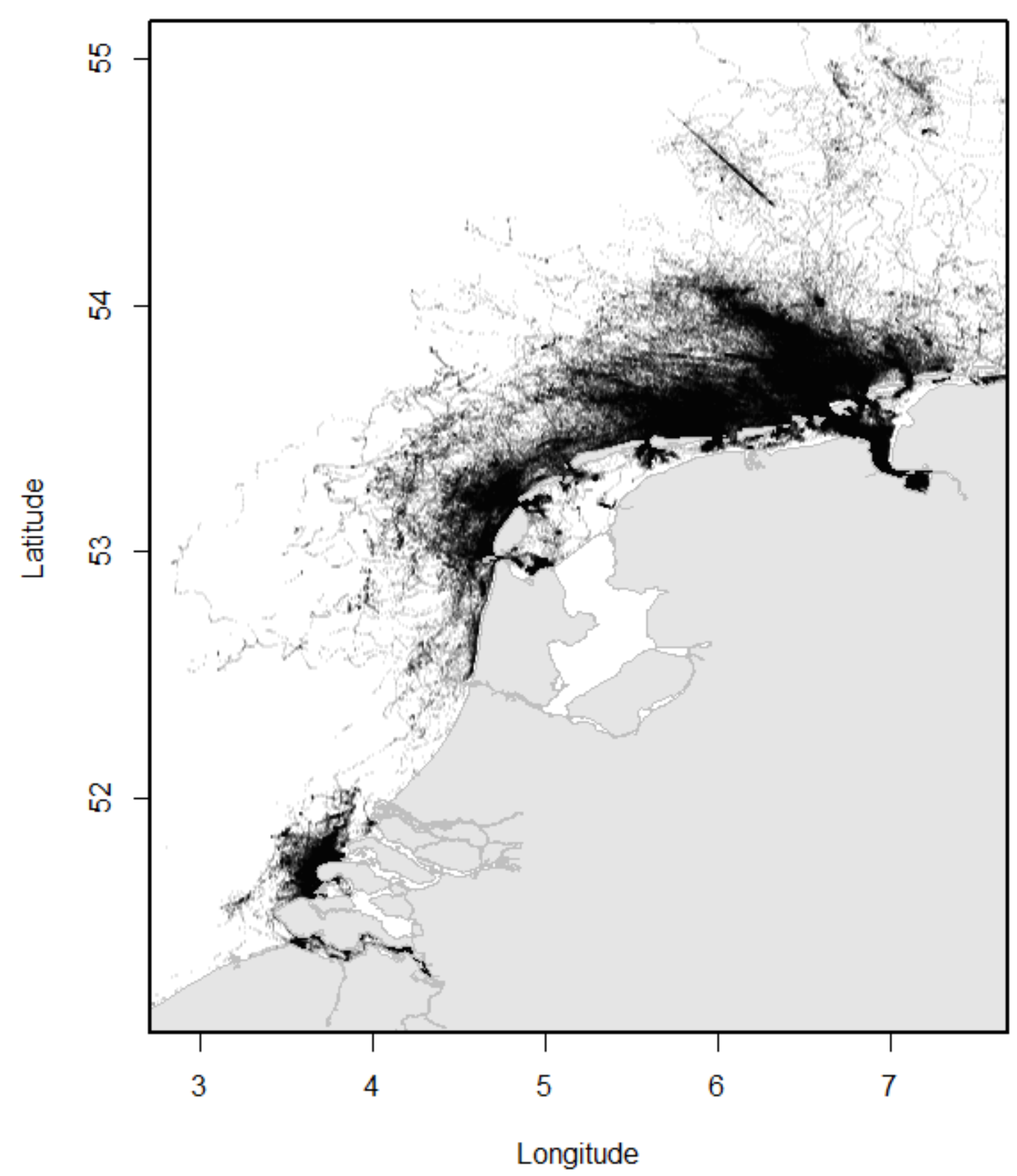

Fig. 4. Distribution of all harbour seal GPS locations used in the analysis.

Harbour seals haul-out regularly on sandbars that are exposed during low-tide, and easily accessible from sea (Fig. 1b). One individual did haul-out on the coast of an inhabited island (i.e. Texel), but none of the tracked seals hauled-out along the west coast of the mainland. 
The average proportion of time the seals haul-out varies within a year, being highest during the months June - September, when animals breed and moult, and when the air temperature is highest. The lowest haul-out proportion occurs during the winter months December - February (Fig. 5).

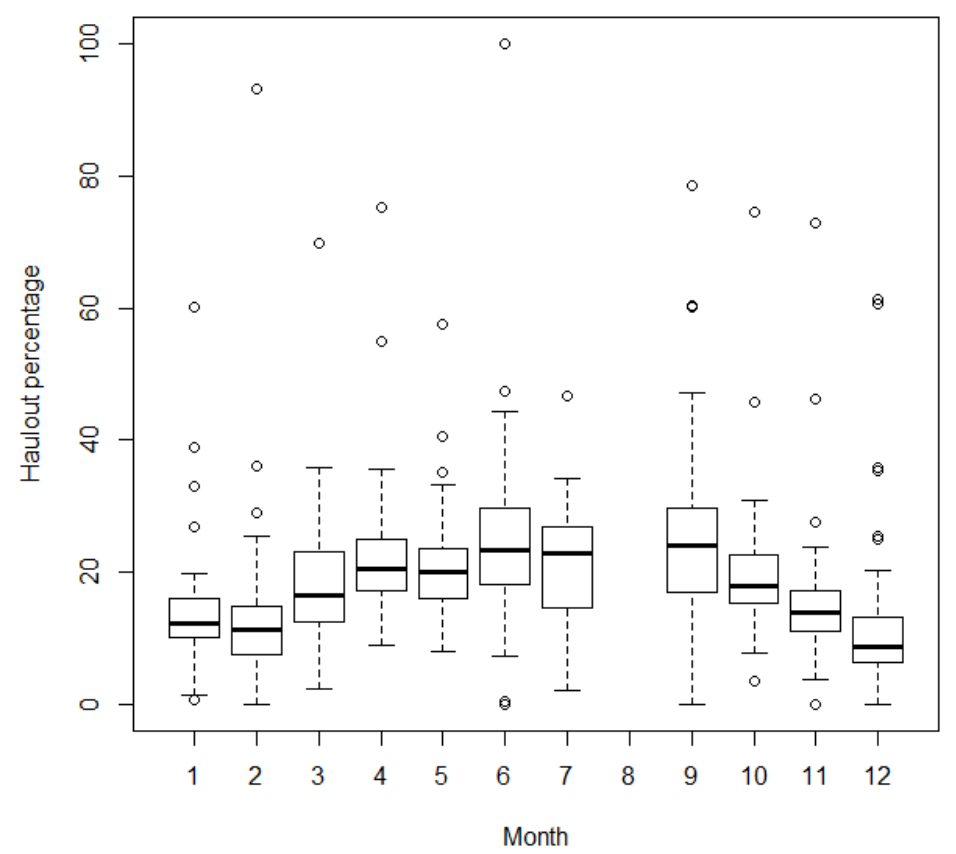

Fig. 5 Intra-annual variability in haul-out percentage. The solid horizontal lines represent the median, the 'hinges' of the box the $1^{\text {st }}$ and $3^{\text {rd }}$ quantile, and the extreme 'whiskers' the minima and maxima, excluding the outliers (open circles). The figure shows box-plots based on monthly-averaged haul-out percentages for each individual, based on the summary data of all individuals (males/females). As tags are shed prior the moult in July, there is no tracking data for August.

\subsection{Distribution and abundance of seals on the haul-out sites}

To estimate the distribution of seals at sea, information on the number of individuals at the haul-out sites is also needed. For the Wadden Sea, we used data from three aerial surveys, representing the distribution of seals during three different periods, namely breeding season (27-6-2015, Fig. 6a), moult (11-8-2015, Fig. 6b) and early spring (18-4-2016, Fig. 6c). Most harbour seals were observed in August, during the annual moult. For example, in August 2015, 7666 harbour seals were counted. Most seals were seen on the sandbars bordering the North Sea, particularly during early spring in April (Fig. 6c). During the breeding season (Fig. 6a), the majority of seals were observed in the eastern Wadden Sea and on sandbars along the channels further south into the Wadden Sea. Substantially less harbour seals use the Delta area. For example, during the moult survey in August 2014, 777 harbour seals were counted, while during the pupping period in July 2014, only 431 harbour seals were counted, of which 57 were pups (Arts, Lilipaly \& Strucker 2016). 
27-06-2015
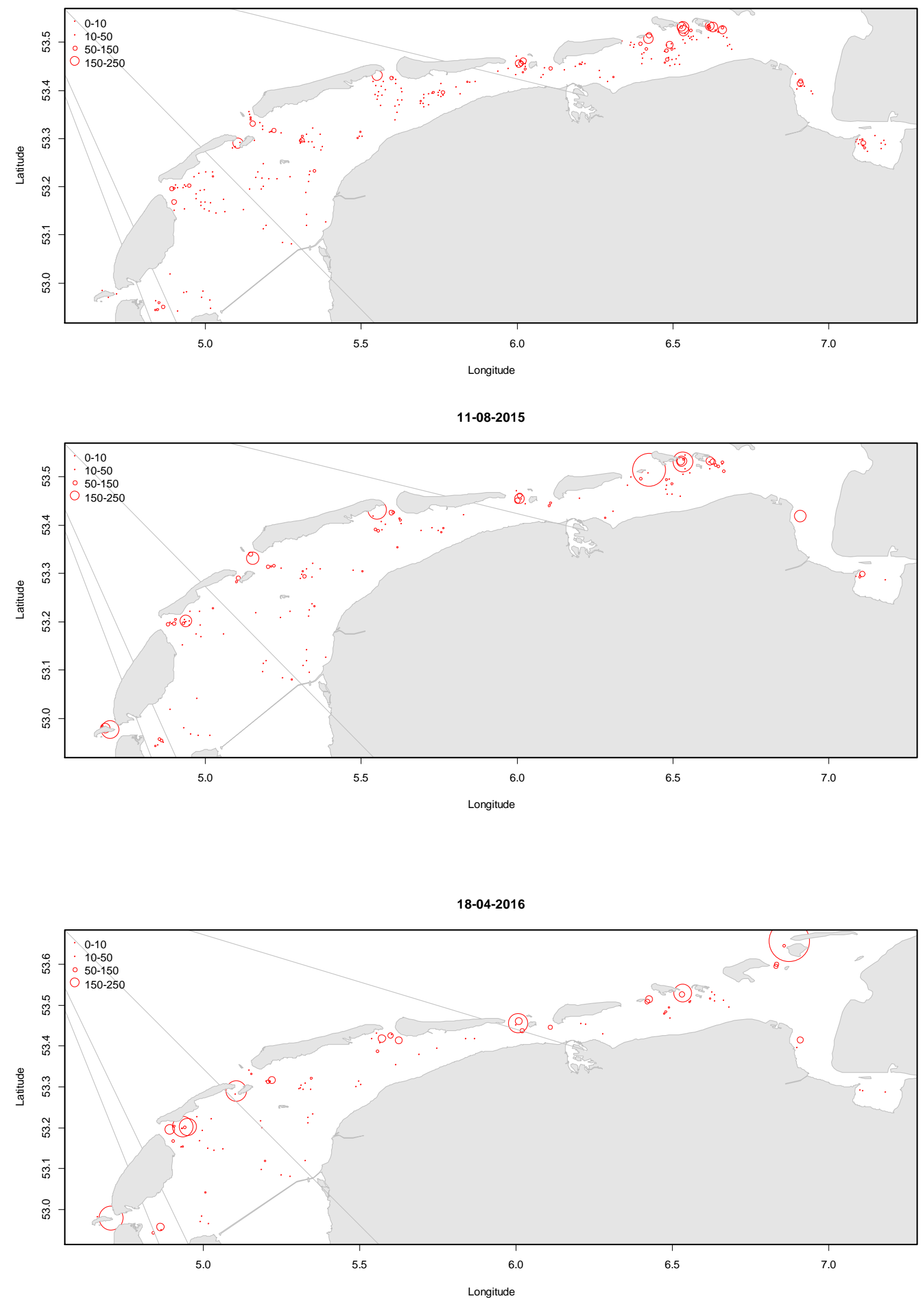

Fig. 6 Aerial survey based counts of harbour seals at haul-outs in the Wadden Sea for three dates, 27 July 2015 (pupping), 11 Aug. 2015 (moult) and 18 April 2016 (harbour seal foraging, grey seal moult). 

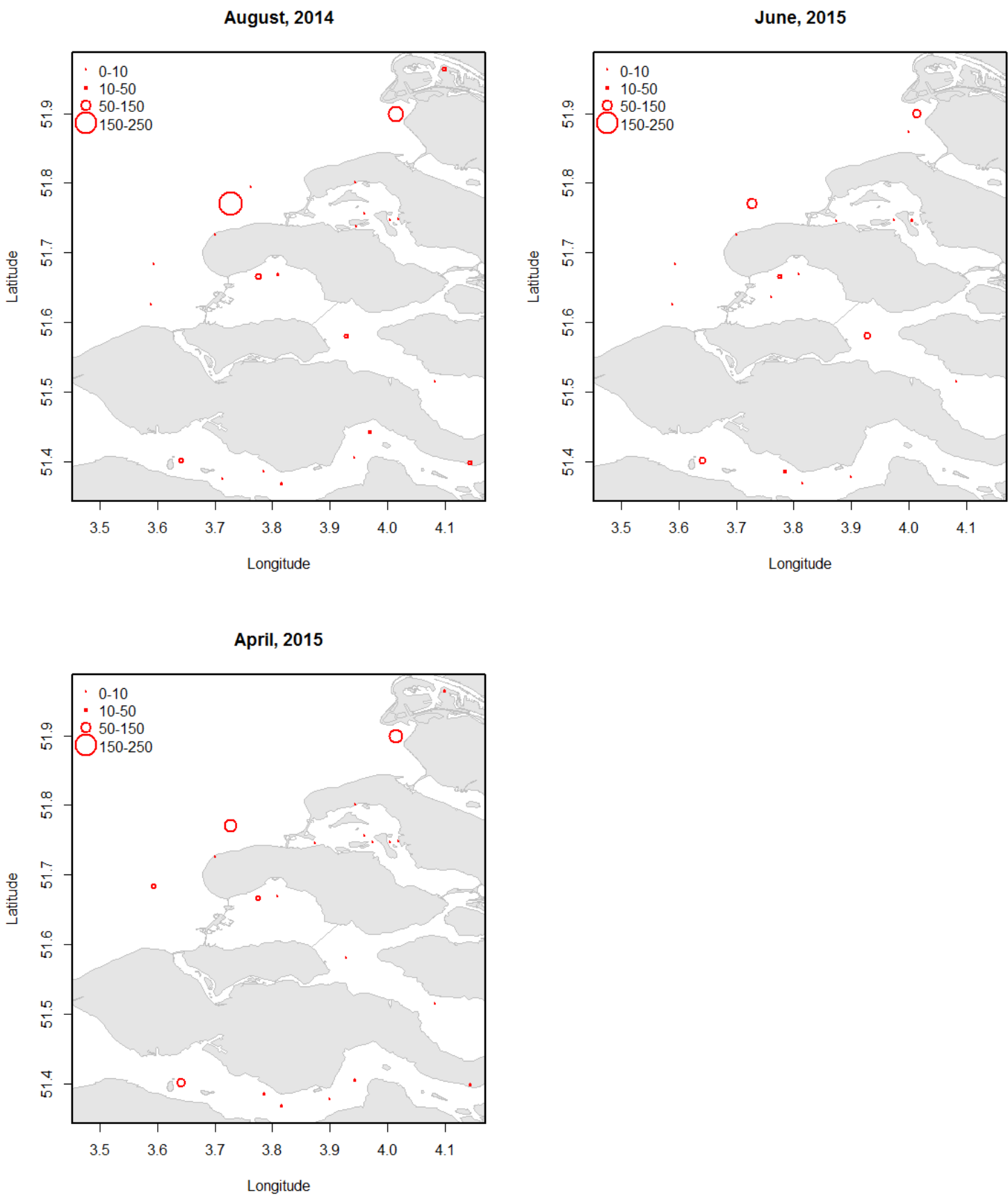

Fig. 7 Aerial survey based counts of harbour seals at haul-outs in the Dutch Delta region for three different periods of the year (Arts, Lilipaly \& Strucker 2016).

When we combine the August counts for the Wadden Sea (7666 in 2015) and those for the Delta (777 in 2014), in total 8443 harbour seals were counted. To correct for the number of seals in the water during the aerial survey counts, this studied used the haul-out probability of $68 \%$ estimated by Ries et al. (1998). Also the individual tracking data could potentially be used to correct for the number of seals in the water. However, currently, the harbour seal surveys used to estimate the population trends are carried out during the moult period (mostly in August), and no tracking data are available for that period. Using the $68 \%$ haul-out probability (Ries et al. 1998), the total numbers using the Wadden Sea and Delta region were estimated at 12416 harbour seals. 


\subsection{Distribution of trips}

Seals undertake forage trips to sea from haul-out sites; consequently their at-sea distribution is heavily influenced by the distance to the haul-out site. Although seals can make trips beyond $80 \mathrm{~km}$, by far most locations recorded are in the proximity of the haul-out from which they depart (Fig. 8). The cumulative distribution of distance from the haul-out varies intra-annually, with seals spending substantially more time away from the haul-out during the winter months (Fig. 8)

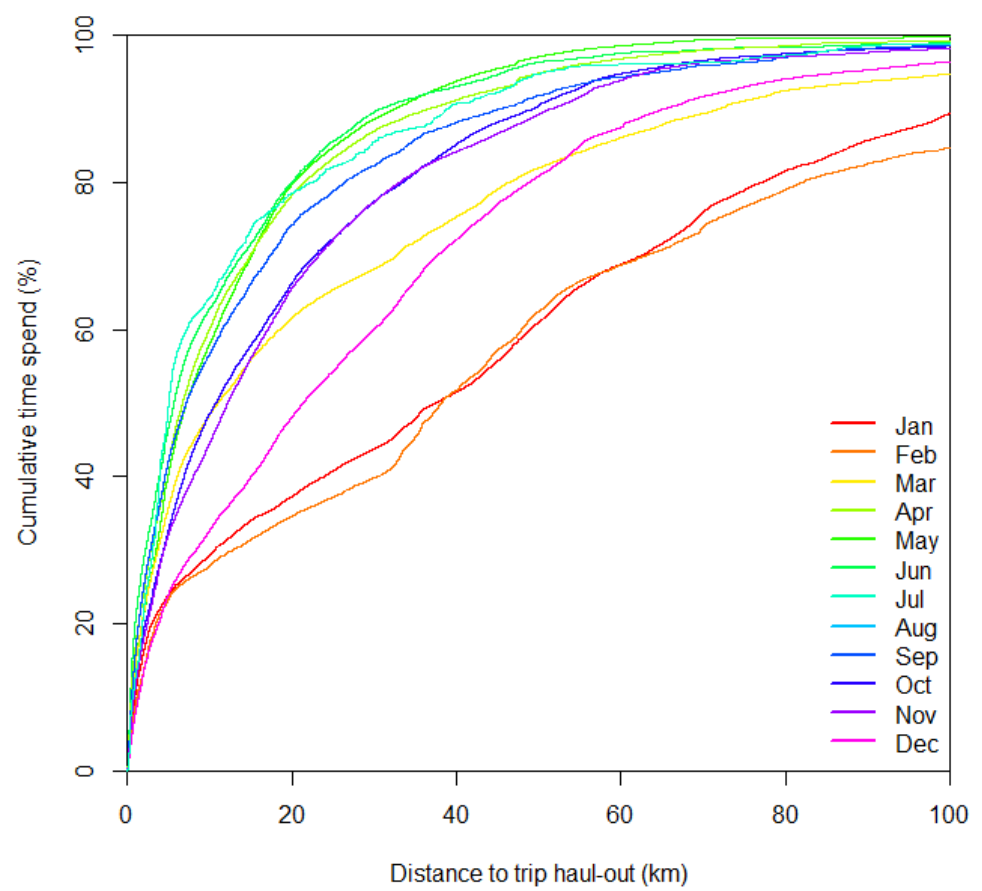

Fig. 8 Time spent at sea (cumulative \%) as a function of distance to the haul-out (i.e. the start haulout for all locations prior to the mid-point of the trip, and the end haul-out for all locations after the mid-point of each trip). During the spring and summer months (April - September), relativly more time was spent near the haul-out sites, while in the cooler months, particularly January and February, much more time was spent further away from haul-outs.

A large number of trips were shorter than 1 hour (Fig. 9a), possibly representing occasions when seals entered the water for a brief period, e.g. to change location or due to disturbance. The second peak in trip duration is around 6 hours, corresponding with half a tidal cycle (Fig. 9a). Most likely these were seals that entered the water during upcoming tide, and hauled out again as soon as the sand bar became available during the falling tide. The next peak was around 17-20 hours, corresponding with skipping one low-tide period, and hauling-out during the next eb-tide. Longer trips occur less frequently, but because they last longer they represent a larger proportion of time (Fig. 9a).

Most often the haul-out duration was approximately 6 hours, representing one low tide period (Fig. $9 b)$, but seals also hauled-out for longer periods. These longer haul-outs likely occured on sandbars that did not flood during high-tide. 


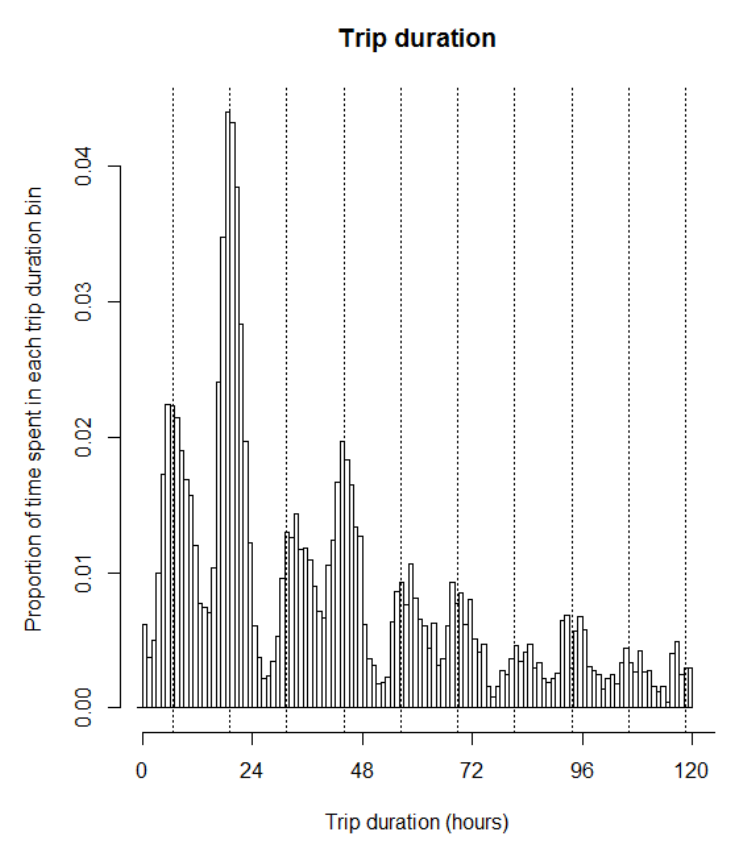

a.

Fig. 9 Frequency distribution of trip duration (a) and haul-out duration (b), weighted by the time spent on each trip and haul-out duration bin, respectively.

\subsection{Preference for environmental variables}

The habitat model included distance to the haul-out, depth and sediment type. As expected from the seal GPS location data, the model estimated a strong decline in habitat use as a function of distance to the haul-out site (Fig. 10), and this relationship varied between months. Seals spent most time relatively near to the haul-out site just after the moult in September, and in late spring and summer. Around January-February, seals undertook the furthest trips. 


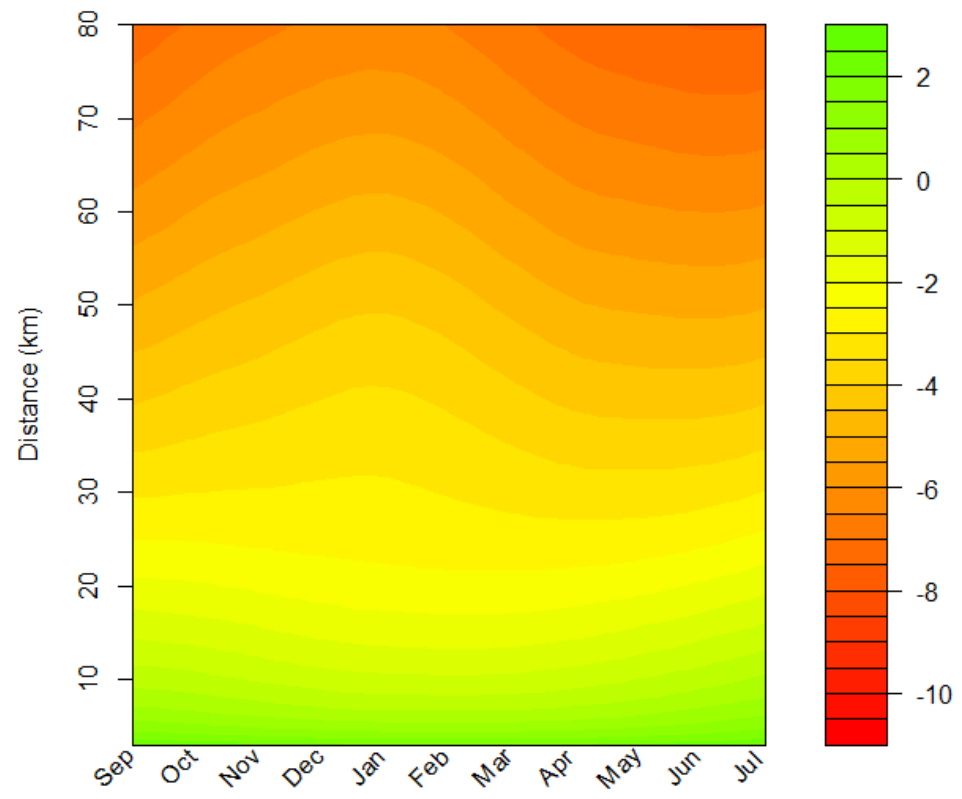

Fig. 10 Relative seal density (on a log-scale) as a function of distance to the haul-out and calendar month. Seal density declines with increasing distance from the haul-out. During the winter months (Dec. - Feb.), seals spent more time away from the haul-out sites (see also Fig. 8).

In relation to depth, the model showed that on average seals preferred regions of $\sim 30 \mathrm{~m}$ depth, and have a lower preference for areas deeper or more shallow (Fig. 11a). Moreover, the model showed that harbour seals generally avoided areas with higher mud-content.

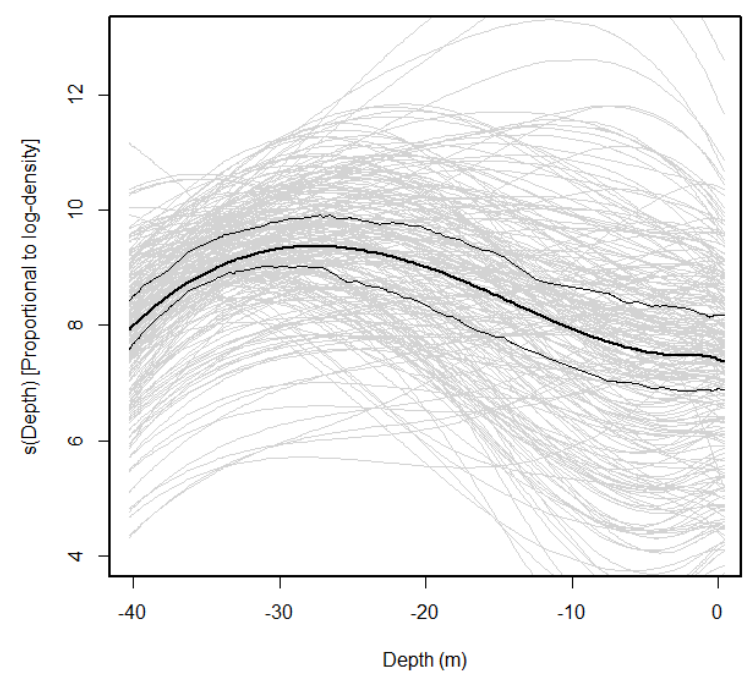

a.

Fig. 11 Variation in seal density as function of the explanatory variable depth (a) and \%mud in the sediment (b). Grey lines represent individual-level random effects, showing the individual variation in preference.

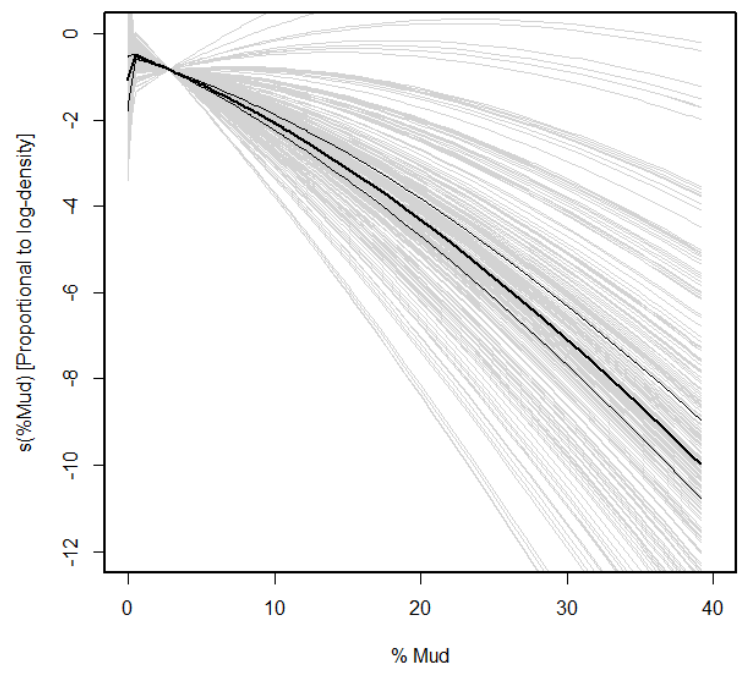

b. 


\subsection{Predicted Spatial distribution}

By combining data on the number of seals on the haul-out sites in the Wadden Sea and Delta region, and the habitat model, the density of seals at sea was estimated. The density estimates varied between seasons. During the winter months, harbour seals 1) spent more time at sea, 2) travelled greater distances from the haul-out, and 3) used haul-out sites that were located closer to the North Sea.

The distribution of harbour seals for two months, September and February, are shown in Fig. 12 and 13. These maps have a $200 \times 200$ m resolution, and reflect seal density (i.e. number of seals per $\mathrm{km} 2$ ). For each month, the density maps are also publically available as ascii rasters (in UTM31N projection). Alternatively, the distribution of seals can be presented as number of seals per $(200 \mathrm{~m} x$ $200 \mathrm{~m}$ ) grid cell. Also these abundance maps are available as ascii rasters. Because there were no seal location data available for August, no predictions were made for this month. One could assume that both the spatial distribution and haul-out probability in August is equal to September, but there are currently no data to support this. 


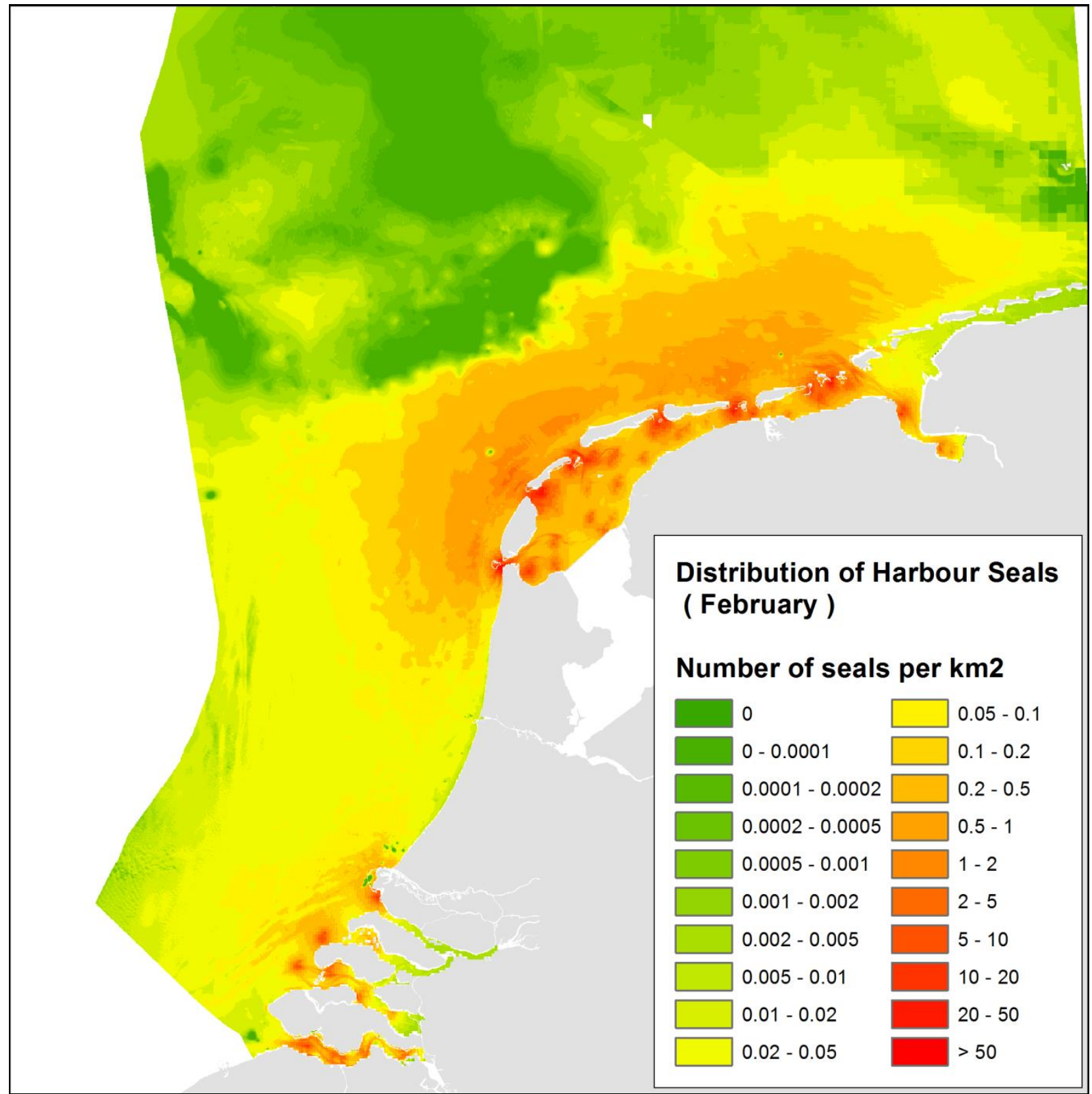

Fig. 12. Predicted spatial distribution (February) of harbour seals making trips from haul-out sites located in the Netherlands. Values represent number of seals per $\mathrm{km}^{2}$. 


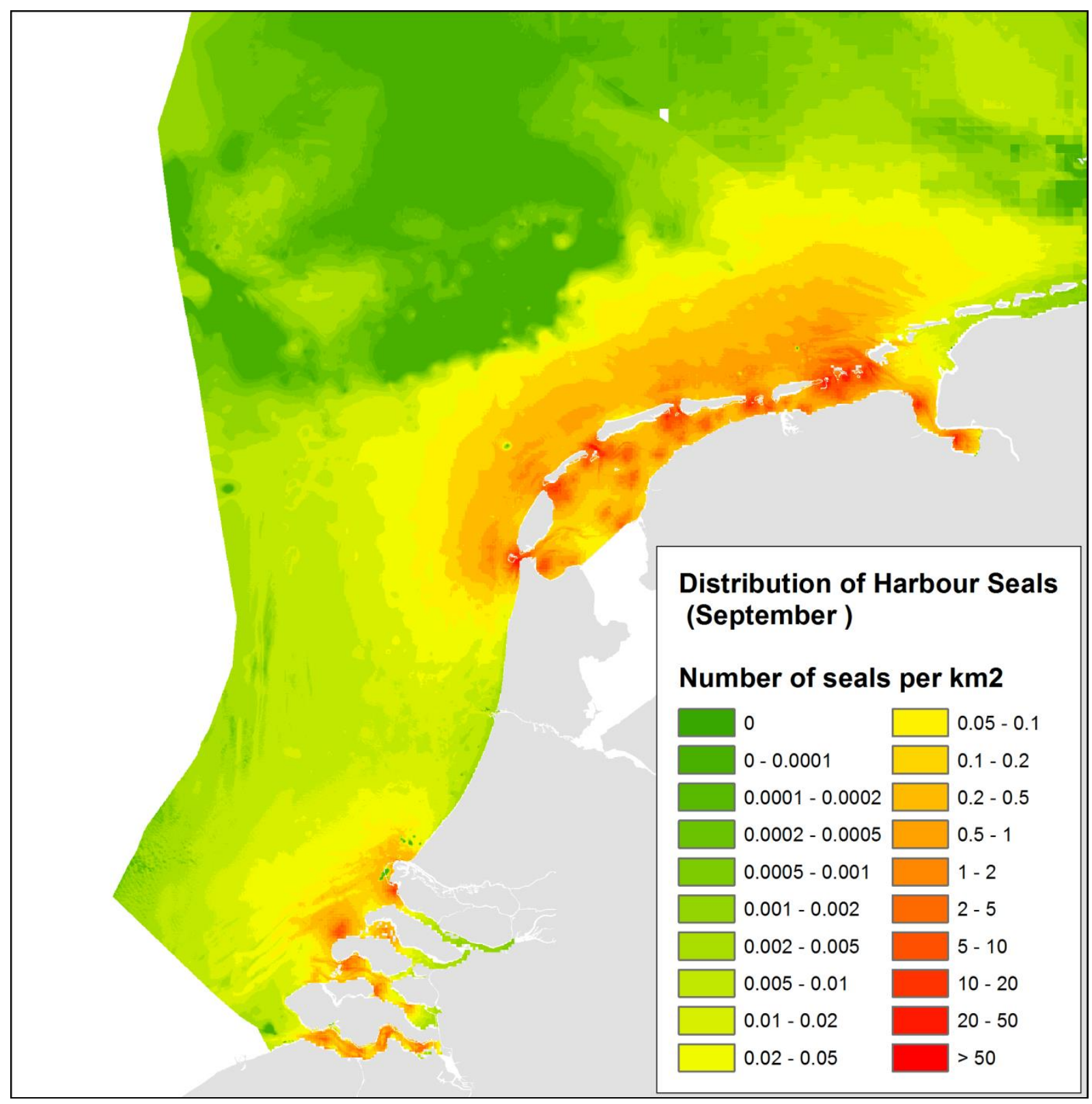

Fig. 13. Predicted spatial distribution (September) of harbour seals making trips from haul-out sites located in the Netherlands. Values represent number of seals per $\mathrm{km}^{2}$.

To directly compare the observed distribution of satellite tracked seals with the model predictions, the habitat model was used simulate the distribution of 12416 harbour seals for each month (see Fig. 14b, $\mathrm{d}$ for September and February, respectively, and Annex 1 for the other months). To facilitate the comparison, also a random selection of 12416 GPS locations was plotted (Fig. 14a, c). 

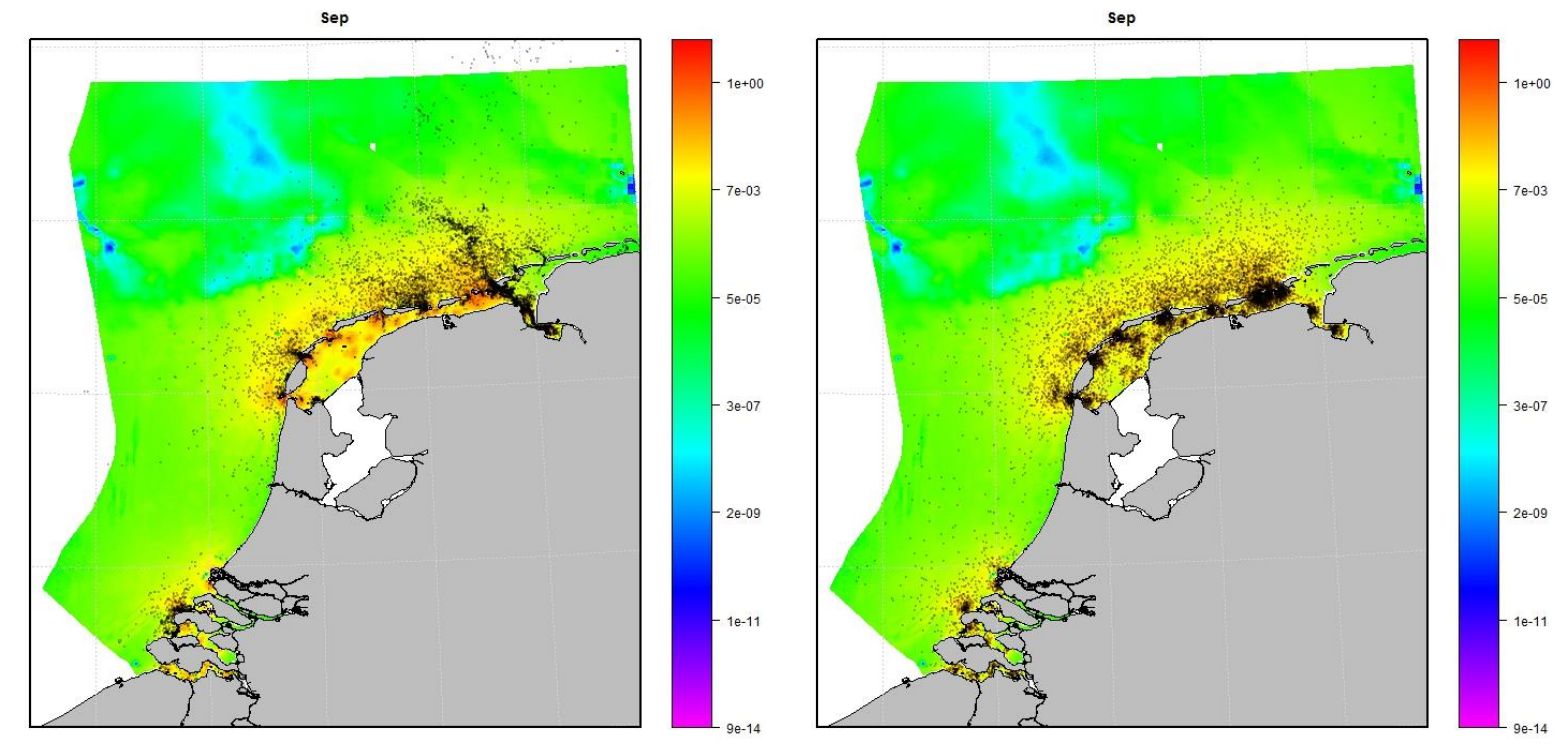

a.

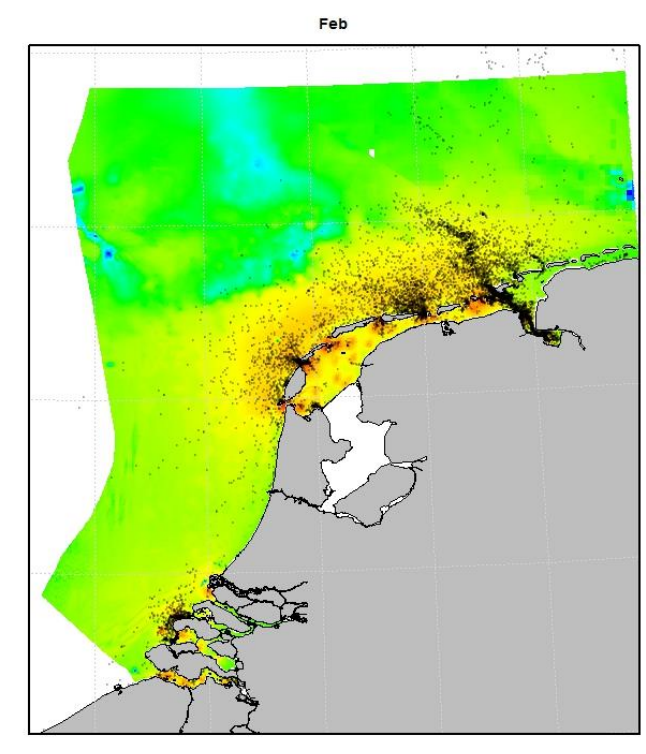

c. b.
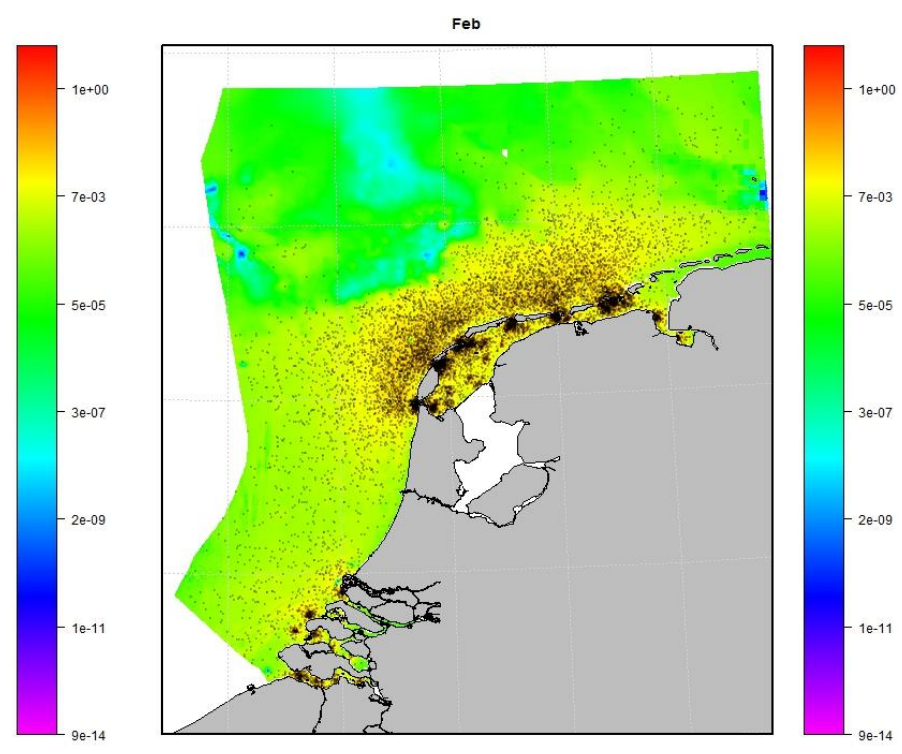

d.

Fig. 14 Predicted distribution (coloured map on log-scale) of harbour seals (number of individuals $/ \mathrm{km}^{2}$ ) in Dutch waters for two months September (a, b) and February (c, d). Overlaid, a sample of true GPS locations $(\mathbf{a}, \mathbf{c})$ and an equal number of locations as predicted by the model (b, d).

In some areas, the model-predicted locations appear to deviate from the sample of observed telemetry observations. This is partly because the seal locations are heavily influenced by sampling effort. For example, 142 of the 225 harbour seals were tagged within the Ems estuary. Consequently, many more telemetry locations were recorded within this region, incorrectly suggesting this is the most heavily used area of the Wadden Sea. The model predictions correct for this sampling bias by taking into account of the number of seals present on the haul-out sites, hence providing a less biased estimate of the distribution of all harbour seals in Dutch waters. 
Using cross-validation, the predictive performance of the habitat model was tested. More specifically, the aim was to test if our estimates of habitat selection for seals from the Ems estuary can be used for predicting the seal distribution elsewhere. Therefore, a model was fitted to location data from seals tagged in the Ems estuary only, and the model prediction was used as covariate to predict the distribution of tagged seals elsewhere. Parameter estimates close to one (and non-zero) for this prediction covariate indicate a strong predictive ability of the habitat model. The estimate was 0.996 (i.e. close to 1 , with $95 \%$ confidence interval: $0.930-1.06$ ), and hence, significantly different from 0. Therefore, it can be concluded that the estimated habitat selection for the Ems region, is informative for the distribution of seals elsewhere. 


\section{Discussion}

\subsection{Distribution and habitat selection of harbour seals in the Dutch waters}

The main aim of this study was to estimate the distribution of all harbour seals making trips from haul-out sites located in the Netherlands. The study uses data from more than 200 GPS-tracked harbour seals, and aerial counts of seals on haul-out sites in the Wadden Sea and the Delta region. The spatial distribution of tagging effort was not equally spread, with the vast majority of individuals being tagged in the Ems Estuary in the North-East of the Netherlands, and near the border with Germany. The main aim of the habitat model is to estimate the species' distribution, while correcting for this sampling bias. The habitat model was fitted to the GPS seal locations, capturing the variations in seal density as a function of environmental variables and using this dependence for spatial predictions for the entire Dutch Wadden Sea and North Sea. The model showed that by far the most variation in density could be explained by distance to the haul-outs. Furthermore, the residual variation in seal density showed a peak preference for regions of $\sim 30 \mathrm{~m}$ deep, and a preference for areas with low mud-content. The harbour seal distribution varied between seasons, with harbour seals using areas away from the haul-out sites more frequently during the winter months, particularly between December and February. To estimate densities at sea and the variation between seasons, the habitat model was used to make spatial predictions for each month, for all the 12416 harbour seals estimated to be present in the Dutch Wadden Sea and Delta region, combined.

\subsection{The importance of accurate land-based survey data to estimate at-sea distribution}

To make accurate population level estimates of at-sea distribution and correct for unequal tagging effort in space, data on the number of seals using the different haul-out sites (derived from the population surveys) was used. The important role of haul-out sites and the number of seals using these is particularly apparent for the coastal zone of the Dutch mainland. The lack of permanent haulout sites along this coast results in a relatively low usage of this region, despite the habitat being apparently suitable. In winter, as the seals undertake longer and further trips, the area was used more intensely. From a modelling perspective, the main advantage of the strong relationship to haul-out location was that even with some tagging effort in different regions within their range, it is possible to make estimates of their distribution at sea.

\subsection{Usage declines with distance to haul-out site}

The tendency of the seals to concentrate in the vicinity of haul-out sites can be explained in several ways. The first is related to minimising travelling costs. Although it is not exactly known why seals haul-out (there might be several reasons, such as resting, reducing thermoregulatory costs, skin maintenance), harbour seals do choose to haul-out regularly. Therefore, if the distribution of prey was uniform, foraging areas in the vicinity of the haul-out sites should be preferred because prey requirements can be fulfilled with less travel required (Matthiopoulos 2003). Trips of 17-20 hours were most common, meaning the seals tended to miss one low-tide opportunity to haul-out, coming back for the next low tide. When travelling at a speed of $\sim 1 \mathrm{~m} / \mathrm{s}$ (which is a reasonable mean travel speed 
for harbour seals), the seals could travel $34 \mathrm{~km}$ from the haul-out. If they do so, little time would remain to forage (although they may search for prey while travelling). So, to maximise foraging time and still haul-out as frequently as possible, seals are expected to forage close to the haul-out site. However, heterogeneity in habitat quality may cause some patches further offshore to be more profitable. Also, seals may deplete prey resources in the vicinity of the colony, forcing animals to go further away. This process is known as density dependent competition and has been observed for other species (e.g. for gannets, see (Wakefield et al. 2013)). Related to this, there appears to be a tendency for seals in this region to forage within a narrow 'passage' north-wards out of the Ems estuary. This could also be the result of food competition with neighbouring colonies, located further East and West. Instead of modelling seal distribution as function of distance to coast, explicitly modelling density dependent competition (if it exists), would be a more mechanistic approach, and possibly would improve predictive performance.

The second reason for higher usage near the colony is that when going to feeding areas, the seals must travel through the intermediate areas. This will show up the areas surrounding the haul-outs as being used intensively. Whether or not the seals fed there, their density is high close to the haul-outs. Theoretically, one could possibly fine-tune the analysis by separating the telemetry data into foraging and non-foraging locations, and developing distribution models for both types of behaviour. For example, dive data could be introduced into the analysis to determine when the seals were likely to be searching for food. Most often, dives to the bottom have been interpreted as feeding dives. However, in the shallow seas around the Dutch coast the dive data shows that seals most often travel close to the bottom while transiting, such that it is difficult to discern whether they are feeding or not. Therefore, with the current available data it is not possible to make an objective classification into feeding and non-feeding types. However, the newly developed accelerometers can measure the seals swim speed underwater and classify prey capture attempts. In the future, this would allow for a better classification into foraging or transiting behaviour.

\subsection{Seasonal variability in their distribution at-sea}

During the winter months (December - February), seals tended to use areas further offshore. One driver of a shift to more distant feeding areas might be that harbour seals reduce prey densities in the vicinity of the haul-out sites. Initially, seals remain near the haul-out sites during breeding and moult periods, but from September onwards start feeding more intensely. During the productive summer months, prey depletion can be compensated by fish growth, but the increase in fish biomass is much less during the winter months, and hence, local prey depletion most likely occurs during the winter months.

Another potential explanation is that there is a shift in distribution of their prey. During spring and summer, the Wadden Sea acts as a nursery area for several species such as flounder and plaice. By August and September, these have reached a length of approximately $10 \mathrm{~cm}$, a size consumed by harbour seals. However, from September onwards the abundance of most demersal fish species in the Wadden Sea and coastal zone slowly declines (Tulp et al. 2016), presumably driven by decreasing water temperature of the shallow Wadden Sea and adjacent coasts. The cold water drives the fish to migrate towards deeper (warmer) waters offshore. Seals may either pursue these fish further offshore or they may switch to other prey species. During a ship-based survey of near-shore waters of the coastal zone in winter 2012, large number of seals were observed near aggregations of sprat and herring (Aarts et al. 2013), which are abundant along the coast in winter (Couperus et al. 2016). The stomach of a single fresh harbour seal which was found dead on the coast ('Schoorl aan Zee') on 
January 24 contained two sprat and 2 herring otoliths. Despite the fact that seals are known to forage on benthic prey, the relatively shallow coastal waters and large wintering clupeid stocks could permit them to access the more pelagic sprat and herring (Wageningen Marine Research, unpublished data).

For the current study, few tracking data were available for the North Sea coast during the winter months (only 5 seals tagged near Texel), but the ship-based surveys and coastal sightings suggest more seals might be present along the west-coast of the Netherlands. This is illustrated by visual observations from the mainland coast that show a strong seasonal pattern, with most harbour seals being sighted between December and February (Fig. 13).

Also the habitat model predicts that most seals are found off the Dutch west-coast during those same months (Dec - Feb, Fig. 8, 10, 12 \& 13). However, the habitat model does not predict high densities directly next to the coast (i.e. the region where the land-based observations of seals are made). Currently, data is collected on harbour seals using the coastal zone during the winter months, and this should improve the model-predictions in this region.

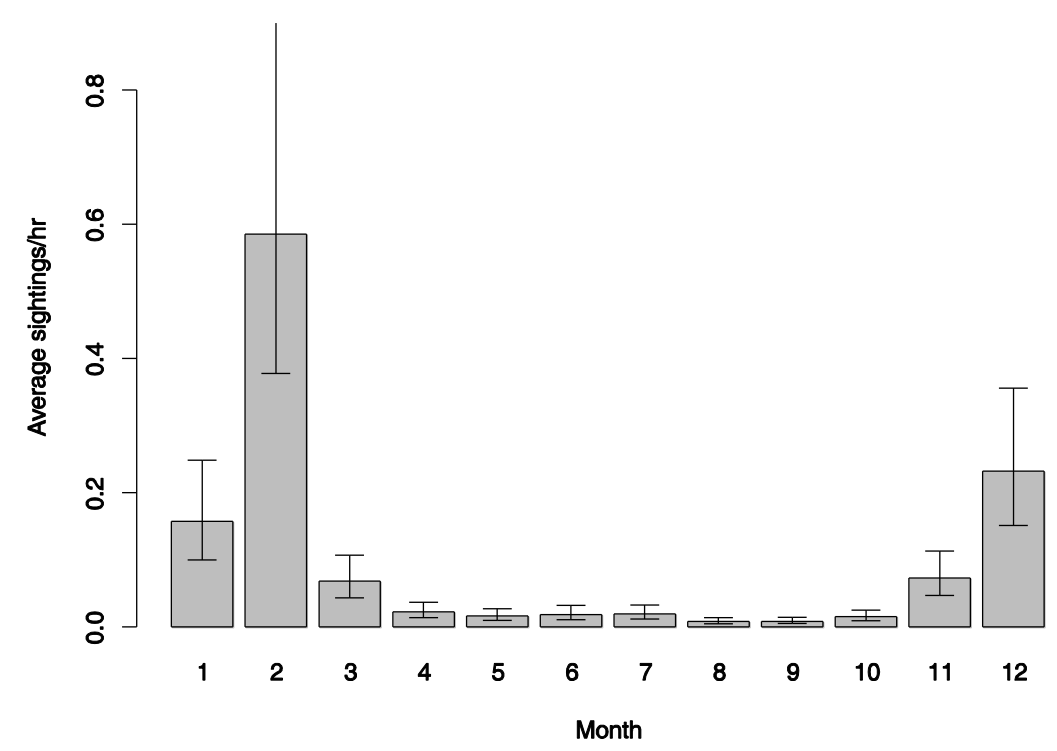

Figure 13. Monthly pattern of number of harbour seals observed per hour (i.e. corrected for effort) during the sea-watches along the Dutch coast, 2009-2012 (Aarts et al. 2013).

During the winter months, seals haul-out less. New analysis (Wageningen Marine Research, unpublished data) suggest that they still spent approximately $40 \%$ of their time within the Wadden Sea, however the time spent on-land is less during the winter months. Haul-out frequency may be related to temperature. Heat transfer in seals occurs through convection, conduction and radiation, which differ in air and water. Generally, heat loss is higher in water. However, if water temperature is substantially warmer than air temperature, the, seals might conserve energy by staying in the water. In December-February, water temperature is higher than air temperature on average.

\subsection{From species density towards cumulative usage}

The objective of this study was to describe the harbour seals' distribution at sea, quantify their selection for certain areas at sea, given local environmental conditions, and use this habitat model to predict the distribution of all harbour seals that haul-out in the Netherlands. These predictions show 
how many seals are likely to be in an area at any given moment, not how many seals may be dependent on specific areas. Thus, for the assessment of the effect of single impact events, e.g. underwater detonations of explosives, such maps can be used to estimate the number of individuals present and therefore exposed and impacted by such an event. However, many human activities, such as seismic surveys or construction of offshore wind farms, have a continuous or intermittent nature. Both during and in-between the sound producing activities, seals can redistribute. In those cases, these 'snap-shot' density estimates could underestimate the number of animals potentially affected.

The distribution maps provided in this study can be used to estimate the number of seals affected. The lower limit can be estimated by using the distribution maps and calculating the number of individuals present within the impact area. This assumes that the same individuals are present during all consecutive sound producing events. For seals, this is an unrealistic assumption, since they regularly return to haul-out sites. An upper limit can be defined by calculating the number of seals exposed during each single sound producing event, and summing these over all events. In addition, one might need to account for the redistribution of seals during the event; e.g. pile-driving may take several hours.

The ultimate objective of an impact assessment is to estimate the effect of human activities on the population as a whole. Whether an activity has an effect, depends (among other things) on the number of individuals exposed, and whether individuals are repeatedly exposed. Multiple exposures to a single individual, could have a larger impact than a single exposure to multiple individuals. To properly tackle this problem it is necessary to develop individual-based movement models (IBMs), and estimate how many individuals use particular regions over time (e.g. Aarts et al. 2016). Such IBMs, or agent-based models, can subsequently be expanded by including the energetic costs of all behavioural activities, such as swimming, resting, reproduction, etc. (Nabe-Nielsen et al. 2014).

\subsection{Limitations}

Although this study provides the first estimate of the distribution of all harbour seals making trips from haul-out sites located in the Netherlands, there are a number of caveats. First of all, most of the tracking data comes from seals tagged in the Ems Estuary and these animals might behave somewhat differently to the rest of the population. As is evident from the aerial surveys, most seals can be found on haul-out sites bordering the North Sea. Therefore, particularly the seals tagged in the Dollard of the Eems Estuary (which is an in-land section of the estuary), are over-represented, given the relatively small number of individuals 'living there. In contrast, the west-coast of the Netherlands was under-presented, particularly for the winter months. Hence, the density estimates there are mostly extrapolations. When comparing a model fitted to data from seals tagged in the Ems estuary, the model still significantly predicts the distribution of seals tagged elsewhere. This illustrate that the distribution and habitat selection observed in one region, is at least to some extent informative for the seal distribution elsewhere.

Also, the tracking was biased toward adult seals. There was no GPS location data available on the distribution of pups during their first months of life (i.e. June - March). It is currently unknown if they remain within the Wadden Sea foraging on smaller-sized fish species, or also feed in higher density fish-grounds further offshore.

The distribution model predicts relatively low seal usage along the Dutch west coast, while a shipbased surveys and coastal sightings suggest high seal usage along the mainland coast, particularly during the winter months (e.g. see Fig. 13). Currently, little seal GPS location data are available for 
this region. The habitat model predicts the highest usage at $\sim 30 \mathrm{~m}$ and lower usage in more shallow waters. If the lower usage of shallow areas is driven by another mechanism, e.g. temperature or partial depletion by seals, the model may describe the distribution well for the region where most telemetry data come from (i.e. the Wadden Sea), but may result in less accurate predictions elsewhere (i.e. coastal zone).

Finally, this study investigated the distribution of seals in relation to natural environmental variables (e.g. depth and sediment type), while human activities that might have influenced the seals' distributions were on-going. Some activities will lead to lower usage of an area. For example, piledriving during the construction of offshore wind-farms deters harbour seals out to $40 \mathrm{~km}$ away (Russell et al. 2016). Also grey seals appear to avoid pile driving (Kirkwood et al. in prep), which will be investigated in future studies. Shipping noise, explosions at sea and seismic surveys may also deter seals. No field or data analysis studies have been carried out to examine the impact of these other anthropogenic activities on harbour seals (but for porpoises see (Thompson et al. 2013; von BendaBeckmann et al. 2015; Aarts et al. 2016), and ringed seals see (Harris, Miller \& Richardson 2001). If these activities have an effect in the North Sea, this may also have influenced the observed distribution of harbour seals.

\subsection{Future changes in distribution?}

In the Wadden Sea, there is preliminary evidence that the population growth rate of harbour seals is declining and the population size might approximate a carrying capacity (Brasseur et al. in prep). However, for the Delta region this is unlikely to be the case. In the 1990's, only a handful of seals remained there, but numbers have steadily increased since then. Moreover, in the region north of the Wadden Sea the distribution of seals appears to be relatively uniform throughout. In contrast, the density of seals offshore from the Delta appears much lower. This suggests that the Delta may not be approaching its carrying capacity and may grow in the coming years. If so, this will affect the number of seals on the haul-out sites and, accordingly, the number of seals at sea. With more seals, their distribution at sea could be expected to change.

Changes in seal numbers might also change the relative distribution at sea. Increasing density of seals at sea, combined with a continuing decline of fish density in the Wadden Sea and Wadden coastal zone (Tulp et al. 2016), could lead to resource depletion near the haul-out sites. If the harbour seal population remains high, areas further away from the colonies (i.e. north and west of the Wadden Sea, and along coastal zone of the Dutch mainland) with less food competition might become more favourable in the future. This could be a slow transition. Seals are long-lived species, and it may take time for harbour seals to discover the more distant foraging grounds. Also, the seals prey species may gradually move further offshore to avoid mortality due to predation. Hence, usage along the Dutch mainland and further offshore, might change in future. On the other hand, if a new Phocine distemper virus (PDV) strikes, killing half of the harbour seal population (Härkönen et al. 2006), this may heavily reduce any density dependent competition. 


\section{Acknowledgements}

First, we thank the Ministry of Economic Affairs (Ministry of EZ), Groningen Sea Port (GSP), ENECO and Gemini for funding the seal GPS transmitters used in this study. We thank the Ministry of EZ for funding the aerial surveys in the Wadden Sea and we thank the pilots, in particular Aad Droge. We thank Floor Arts for providing the data from the most recent seal counts in the Delta region, obtained by MWTL and funded by Rijkswaterstaat The sediment data was kindly provided by Sytse van Heeteren and Patrick Kiden (TNO) and Jennifer Valerius (BSH). We thank everyone who assisted in the field, particularly Piet-Wim van Leeuwen, Andre Meijboom, Hans Verdaat, and the crew of the Wadden Unit. Finally, we thank RWS (our contacts were Aylin Erkman, Inger van den Bosch and Suzanne Lubbe) for funding this research project and their constructive comments. All permits required to enter protected areas and handle seals during field procedures were obtained from the appropriate authorities. These included a permit under the Dutch Nature Protection Act (Natuurbeschermingswet) given by the Province of Friesland, a permit under the Flora and Fauna Act (Flora en Fauna Wet) given by the Dutch government and protocols approved by an animal ethics committee (Dier Ethische Commissie, DEC) of the Royal Netherlands Academy of Science (Koninklijke Nederlandse Academie voor Wetenschappen, KNAW). 


\section{$6 \quad$ Literature cited}

Aarts, G., von Benda-Beckmann, A.M., Lucke, K., Sertlek, H.Ö., van Bemmelen, R., Geelhoed, S.C. V, Brasseur, S., Scheidat, M., Lam, F.-P.A. \& Slabbekoorn, H. (2016) Harbour porpoise movement strategy affects cumulative number of animals acoustically exposed to underwater explosions. Marine Ecology Progress Series, 557, 261-275.

Aarts, G.M., Brasseur, S.M.J.M., Geelhoed, S.C. V, Bemmelen, R.S.A. van \& Leopold, M.F. (2013) Grey and Harbour Seal Spatiotemporal Distribution along the Dutch West Coast. IMARES, Den Burg.

Aarts, G., MacKenzie, M., McConnell, B., Fedak, M. \& Matthiopoulos, J. (2008) Estimating space-use and habitat preference from wildlife telemetry data. Ecography, 31, 140-160.

Arts, F.A., Lilipaly, S. \& Strucker, R.C.W. (2016) Watervogels En Zeezoogdieren in de Zoute Delta 2014/2015. RWS Waterdienst BM, Middelburg.

Austin, D.D., Bowen, W.W.D. \& McMillan, J.J.I.

file:///F:/endnote\%20paper/Austin_etal_2004_Oikos_Intraspecific_variation_in_movement.pd. (2004) Intraspecific variation in movement patterns: Modeling individual behaviour in a large marine predator. Oikos, 105, 15-30.

Bailey, H., Hammond, P.S. \& Thompson, P.M. (2014) Modelling harbour seal habitat by combining data from multiple tracking systems. Journal of Experimental Marine Biology and Ecology, 450, 30-39.

von Benda-Beckmann, A.M., Aarts, G.M., Sertlek, O.S., Lucke, K., Bemmelen, R. van, Wees, R.M.M. van, Verboom, W.C., Kastelein, R.A., Ketten, D.R., Lam, F.-P.A., Kirkwood, R.L. \& Ainslie, M.A. (2015) Assessing the Impact of Underwater Clearance of Historical Explosives on Harbour Porpoises (Phocoena Phocoena) in the Southern North Sea. Aquatic Mammals, 41, 503-523.

Brasseur, S.M.J.M., Aarts, G.M., Bravo Rebolledo, E., Cremer, J.S.M., Fey-Hofstede, F.E., Geelhoed, S.C. V, Lindeboom, H.J., Lucke, K., Machiels, M.A.M., Meesters, H.W.G., Scholl, M.M., Teal, L.R. \& Witte, R.H. (2011) Zeezoogdieren in de Eems: Studie Naar de Effecten van Bouwactiviteiten van GSP, RWE En NUON in de Eemshaven in 2010 (Herzien). IMARES, Den Burg.

Brasseur, S.M.J.M. \& Kirkwood, R.J. (2015) Seal Monitoring and Evaluation for the Gemini Offshore Windpark: Pre-Construction, TO - 2014 Report. IMARES, Den Burg.

Brasseur, S.M.J.M., Polanen-Petel, T. van Geelhoed, S.C.V., Aarts, G.M. \& Meesters, H.W.G. (2010) Zeezoogdieren in de Eems; Studie Naar de Effecten van Bouwactiviteiten van GSP, RWE En NUON in de Eemshaven in 2009.

Brasseur, S.M.J.M., Polanen Petel, T. van, Scheidat, M., Meesters, H.W.G., Verdaat, J.P., Cremer, J.S.M. \& Dijkman, E.M. (2009a) Zeezoogdieren in de Eems: Evaluatie van de Vliegtuigtellingen van Zeezoogdieren Tussen Oktober 2007 En September 2008. Wageningen IMARES.

Brasseur, S.M.J.M., Polanen Petel, T. van, Scheidat, M., Meesters, H.W.G., Verdaat, J.P., Cremer, J.S.M. \& Dijkman, E.M. (2009b) Zeezoogdieren in de Eems Evaluatie van de Vliegtuigtellingen van Zeezoogdieren Tussen Oktober 2007 En September 2008. IMARES, Texel.

Cordes, L. \& Thompson, P. (2015) Mark-resight estimates of seasonal variation in harbor seal abundance and site fidelity. Population Ecology, 1-6.

Costa, D.P., Robinson, P.W., Arnould, J.P.Y., Harrison, A.-L., Simmons, S.E., Hassrick, J.L., Hoskins, A.J., Kirkman, S.P., Oosthuizen, H., Villegas-Amtmann, S. \& Crocker, D.E. (2010) Accuracy of ARGOS Locations of Pinnipeds at-Sea Estimated Using Fastloc GPS. PLOS ONE, 5, e8677.

Couperus, B., Gastauer, S., Fässler, S.M.M., Tulp, I., van der Veer, H.W. \& Poos, J.J. (2016) Abundance and tidal behaviour of pelagic fish in the gateway to the Wadden Sea. Journal of Sea Research, 109, 4251.

Cowles, J.D., Henson, S.M., Hayward, J.L. \& Chacko, M.W. (2013) A METHOD FOR PREDICTING HARBOR SEAL (PHOCA VITULINA) HAULOUT AND MONITORING LONG-TERM POPULATION TRENDS WITHOUT TELEMETRY. Natural Resource Modeling, 26, 605-627.

Cronin, M.A. \& McConnell, B.J. (2008) SMS seal: A new technique to measure haul-out behaviour in marine vertebrates. Journal of Experimental Marine Biology and Ecology, 362, 43-48.

Cronin, M.A., Zuur, A.F., Rogan, E. \& McConnell, B.J. (2010) Using mobile phone telemetry to investigate the 
haul-out behaviour of harbour seals Phoca vitulina vitulina. Endangered Species Research, 10, 255267.

Dujon, A.M., Lindstrom, R.T. \& Hays, G.C. (2014) The accuracy of Fastloc-GPS locations and implications for animal tracking. Methods in Ecology and Evolution, n/a-n/a.

Galatius, A., Brasseur, S.M.J.M., Czeck, R., Jensen, L.F., Körber, P., Ralf, P., Siebert, U., Teilman, J. \& Klöpper, S. (2015) Trilateral Seal Expert Group (TSEG). Aerial surveys of Harbour Seals in the Wadden Sea in 2015. Moderate impact of the 2014 influenza epidemic, http://www.waddenseasecretariat.org/news/news/Seals/Annual-reports/seals2012.html

Hammond, P., Berggren, H., Benke, L., Borchers, D.A., Collet, P., Heide-Jørgensen, M.P., Heimlich, S.S., Hiby, A., Leopold, M.F. \& N. Øien, P.S. (2002) Abundance of harbour porpoise and other cetaceans in the North Sea and adjacent waters. Journal of Applied Ecology, 39, 361-376.

Härkönen, T., Dietz, R., Reijnders, P., Teilmann, J., Harding, K., Hall, A., Brasseur, S., Siebert, U., Goodman, S.J., Jepson, P.D., Rasmussen, T.D. \& Thompson, P. (2006) A review of the 1988 and 2002 phocine distemper virus epidemics in European harbour seals. Diseases Of Aquatic Organisms, 68, 115-130.

Härkönen, T., Harding, K.C. \& Lunneryd, S.G. (1999) Age- and sex-specific behaviour in harbour seals Phoca vitulina leads to biased estimates of vital population parameters. Journal of Applied Ecology, 36, 825841.

Harris, R.E., Miller, G.W. \& Richardson, W.J. (2001) Seal responses to airgun sounds during summer seismic surveys in the Alaskan Beaufort sea. Marine Mammal Science, 17, 795-812.

Jones, E.L., McConnell, B.J., Smout, S., Hammond, P.S., Duck, C.D., Morris, C.D., Thompson, D., Russell, D.J.F., Vincent, C., Cronin, M., Sharples, R.J. \& Matthiopoulos, J. (2015) Patterns of space use in sympatric marine colonial predators reveal scales of spatial partitioning. Marine Ecology Progress Series, 534, 235-249.

Kirkwood, R.L., Aarts, G.M. \& Brasseur, S.M.J.M. (2015) Seal Monitoring and Evaluation for the Luchterduinen Offshore Wind Farm: 2. Tconstruction - 2014 Report.

Kirkwood, R., Bos, O. \& Brasseur, S. (2014) Seal Monitoring and Evaluation for the Luchterduinen Offshore Wind Farm 1. TO - 2013 Report. Rep No C067/14, IMARES Wageningen UR.

Matthiopoulos, J. (2003) The use of space by animals as a function of accessibility and preference. Ecological Modelling, 159, 239-268.

McConnell, B.J., Chambers, C. \& Fedak, M. (1991) Diving Behaviour of Southern Elephant Seals Relayed by ServiceArgos. 4th European International Conference on Wildlife Telemetry p. 58. Aberdeen.

Meesters, E.H.W.G., Reijnders, P.J.H., Brasseur, S.M.J.M., Tougaard, J., Stebe, M., Siebert, U. \& Härkönen, T. (2007) ) An Effective Survey Design for Harbour Seals in the Wadden Sea: Tuning Trilateral Seal Agreement and EU-Habitat Directive Requirement.

Myers, R.A. \& Bowen, W.D. (1989) Estimating Bias in Aerial Surveys of Harp Seal Pup Production. The Journal of Wildlife Management, 53, 361-372.

Nabe-Nielsen, J., Sibly, R.M., Tougaard, J., Teilmann, J. \& Sveegaard, S. (2014) Effects of noise and bycatch on a Danish harbour porpoise population. Ecological Modelling, 272, 242-251.

Ramsay, J.O. \& Silverman, B. (2005) Functional Data Analysis. Springer-Verlag, New York.

Reijnders, P.J.H. (1978) Recruitment in the Harbor Seal (Phoca vitulina) Population in the Dutch Wadden Sea. Journal of Sea Research, 12, 164-179.

Reijnders, P.J.H., Abt, K.F., Brasseur, S.M.J.M., Tougaard, J., Siebert, U. \& Vareschi, E. (2003) Sense and sensibility in evaluating aerial counts of harbour seals in the Wadden Sea. Wadden Sea Newsletter, 912.

Reijnders, P.J.H., Ries, E.H., Tougaard, J., Norgaard, N., Heidemann, G., Schwarz, J.A., Vareschi, E. \& Traut, I.M. (1997) Population development of harbour seals Phoca vitulina in the Wadden Sea after the 1988 virus epizootic. Journal of Sea Research, 38, 161-168.

Ries, E.H., Hiby, L.R. \& Reijnders, P.J.H. (1998) Maximum likelihood population size estimation of harbour seals in the Dutch Wadden Sea based on a mark-recapture experiment. Journal of Applied Ecology, 35, 332-339.

Russell, D.J.F., Hastie, G.D., Thompson, D., Janik, V.M., Hammond, P.S., Scott-Hayward, L.A.S., Matthiopoulos, J., Jones, E.L. \& McConnell, B.J. (2016) Avoidance of wind farms by harbour seals is 
limited to pile driving activities (ed S Votier). Journal of Applied Ecology.

Sharples, R.J., Mackenzie, M.L. \& Hammond, P.S. (2009) Estimating seasonal abundance of a central place forager using counts and telemetry data. Marine Ecology Progress Series, 378, 289-298.

Sharples, R.J., Moss, S.E., Patterson, T.A. \& Hammond, P.S. (2012) Spatial Variation in Foraging Behaviour of a Marine Top Predator (<italic $>$ Phoca vitulina </italic $>$ ) Determined by a Large-Scale Satellite Tagging Program. PLOS ONE, 7, e37216.

Siniff, D., Reichle, R., Hofman, J.R. \& Kuehn, D. (1975) Movements of Weddell Seals in McMurdo Sound, Antarctica, as Monitored by Telemetry. Rapp. P.-v. Reun. Cons. int. Explor. Mer, 169, 387-393.

Teilmann, J., Rigét, F. \& Harkonen, T. (2010) Optimizing survey design for Scandinavian harbour seals: Population trend as an ecological quality element. ICES Journal of Marine Science, 67, 952-958.

Thompson, P.M., Brookes, K.L., Graham, I.M., Barton, T.R., Needham, K., Bradbury, G. \& Merchant, N.D. (2013) Short-term disturbance by a commercial two-dimensional seismic survey does not lead to longterm displacement of harbour porpoises. Proceedings of the Royal Society B-Biological Sciences, 280, 20132001.

Thompson, P.P.M., McConnell, B.B.J., Tollit, D.D.J., Mackay, A.A., Hunter, C.C. \& Racey, P.P.A. file:///F:/endnote\%20paper/Thompson_etal_1996_JAE_Comparative_distribution_movements_and_di et. pd. (1996) Comparative distribution, movements and diet of harbour and grey seals from the Moray Firth, NE Scotland. The Journal of applied ecology, 33, 1572-1584.

Thompson, P.M., Tollit, D.J., Wood, D., Corpe, H.M., Hammond, P.S. \& Mackay, A. (1997) Estimating harbour seal abundance and status in an estuarine habitat in north-east Scotland. Journal of Applied Ecology, 34, 43-52.

Tollit, D.J., Black, A.D., Thompson, P.M., Mackay, A., Corpe, H.M., Wilson, B., Parijs, S.M., Grellier, K. \& Parlane, S. (1998) Variations in harbour seal Phoca vitulina diet and dive-depths in relation to foraging habitat. Journal of Zoology, 244, 209-222.

Tollit, D.J., Thompson, P.M. \& Greenstreet, S.P.R. (1997) Prey selection by harbour seals, Phoca vitulina , in relation to variations in prey abundance. Canadian Journal of Zoology, 75, 1508-1518.

Tulp, I., van der Veer, H.W., Walker, P., van Walraven, L. \& Bolle, L.J. (2016) Can guild- or site-specific contrasts in trends or phenology explain the changed role of the Dutch Wadden Sea for fish? Journal of Sea Research.

Wakefield, E.D., Bodey, T.W., Bearhop, S., Blackburn, J., Colhoun, K., Davies, R., Dwyer, R.G., Green, J.A., Grémillet, D., Jackson, A.L., Jessopp, M.J., Kane, A., Langston, R.H.W., Lescroël, A., Murray, S., Le Nuz, M., Patrick, S.C., Péron, C., Soanes, L.M., Wanless, S., Votier, S.C. \& Hamer, K.C. (2013) Space partitioning without territoriality in gannets. Science, 341, 68-70.

Zanden, V.H.B., Bjorndal, K.A., Reich, K.J. \& Bolten, A.B. (2010) Individual specialists in a generalist population: results from a long-term stable isotope series. Biol. Lett. October 23, 2010 6:711-714; published online before print March 24, 2010, doi:10.1098/rsbl.2010.0124. 


\section{$7 \quad$ Quality Assurance}

Wageningen Marine Research utilises an ISO 9001:2008 certified quality management system (certificate number: 187378-2015-AQ-NLD-RvA). This certificate is valid until 15 September 2018. The organisation has been certified since 27 February 2001. The certification was issued by DNV Certification B.V.

Furthermore, the chemical laboratory at IJmuiden has NEN-EN-ISO/IEC 17025:2005 accreditation for test laboratories with number L097. This accreditation is valid until $1^{\text {th }}$ of April 2017 and was first issued on 27 March 1997. Accreditation was granted by the Council for Accreditation. The chemical laboratory at IJmuiden has thus demonstrated its ability to provide valid results according a technically competent manner and to work according to the ISO 17025 standard. The scope (L097) of de accredited analytical methods can be found at the website of the Council for Accreditation (www.rva.nl).

On the basis of this accreditation, the quality characteristic $Q$ is awarded to the results of those components which are incorporated in the scope, provided they comply with all quality requirements. The quality characteristic $Q$ is stated in the tables with the results. If, the quality characteristic $Q$ is not mentioned, the reason why is explained.

The quality of the test methods is ensured in various ways. The accuracy of the analysis is regularly assessed by participation in inter-laboratory performance studies including those organized by QUASIMEME. If no inter-laboratory study is available, a second-level control is performed. In addition, a first-level control is performed for each series of measurements.

In addition to the line controls the following general quality controls are carried out:

- Blank research.

- Recovery.

- Internal standard

- Injection standard.

- Sensitivity.

The above controls are described in Wageningen Marine Research working instruction ISW 2.10.2.105. If desired, information regarding the performance characteristics of the analytical methods is available at the chemical laboratory at IJmuiden.

If the quality cannot be guaranteed, appropriate measures are taken. 


\section{Justification}

Report number:

Project Number:
C118/16

4312100034

The scientific quality of this report has been peer reviewed by a colleague scientist and a member of the Management Team of Wageningen Marine Research

Approved:

Dr. J.J. Poos

Researcher

Signature:

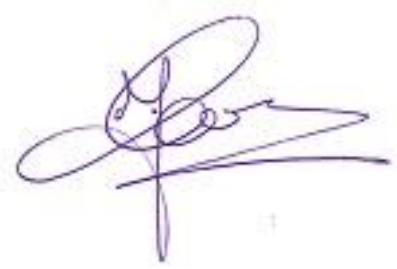

Date:

$8^{\text {th }}$ December 2016

Approved:

Drs. J. Asjes

Manager Integration

Signature:

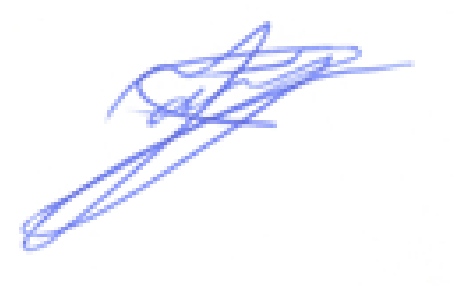

Date:

$8^{\text {th }}$ December 2016 


\section{Annex 1 Seasonal distribution of seal GPS locations}

Fig. A1 Predicted distribution maps for each month, overlaid with a random realization of seals based on the model (left) and a selection of seal GPS locations for that month (right). For more details, see Fig. 12
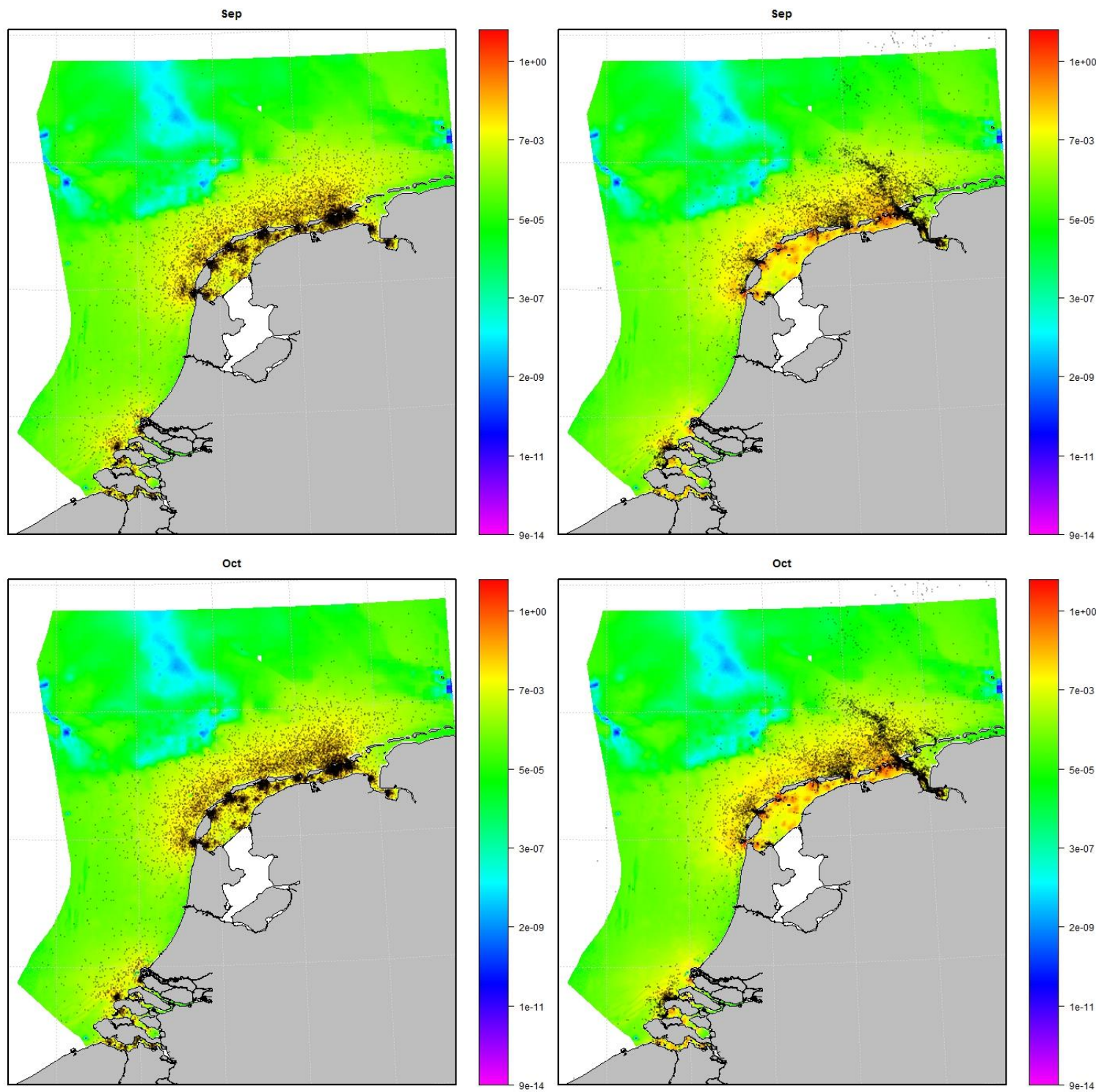


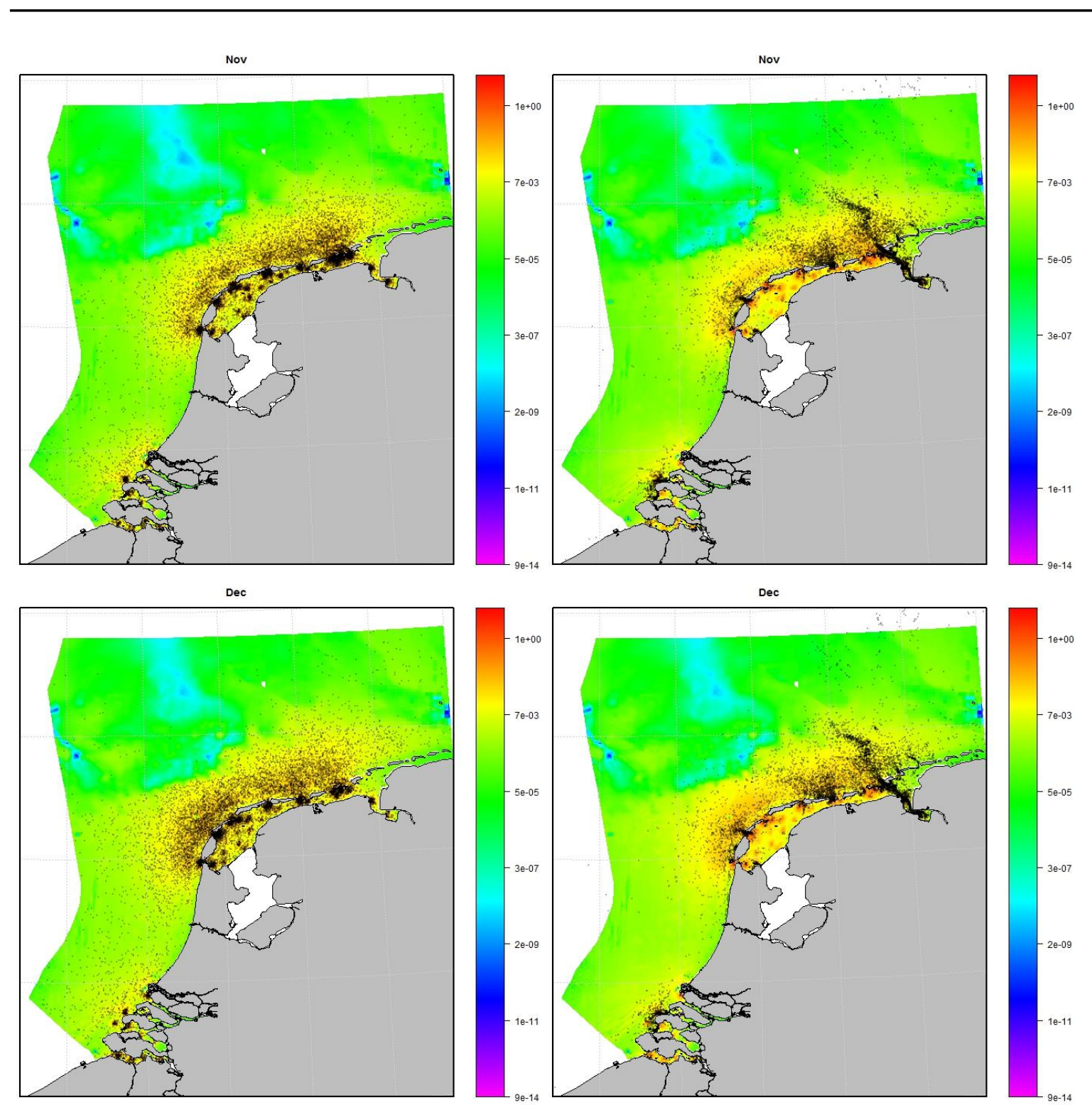



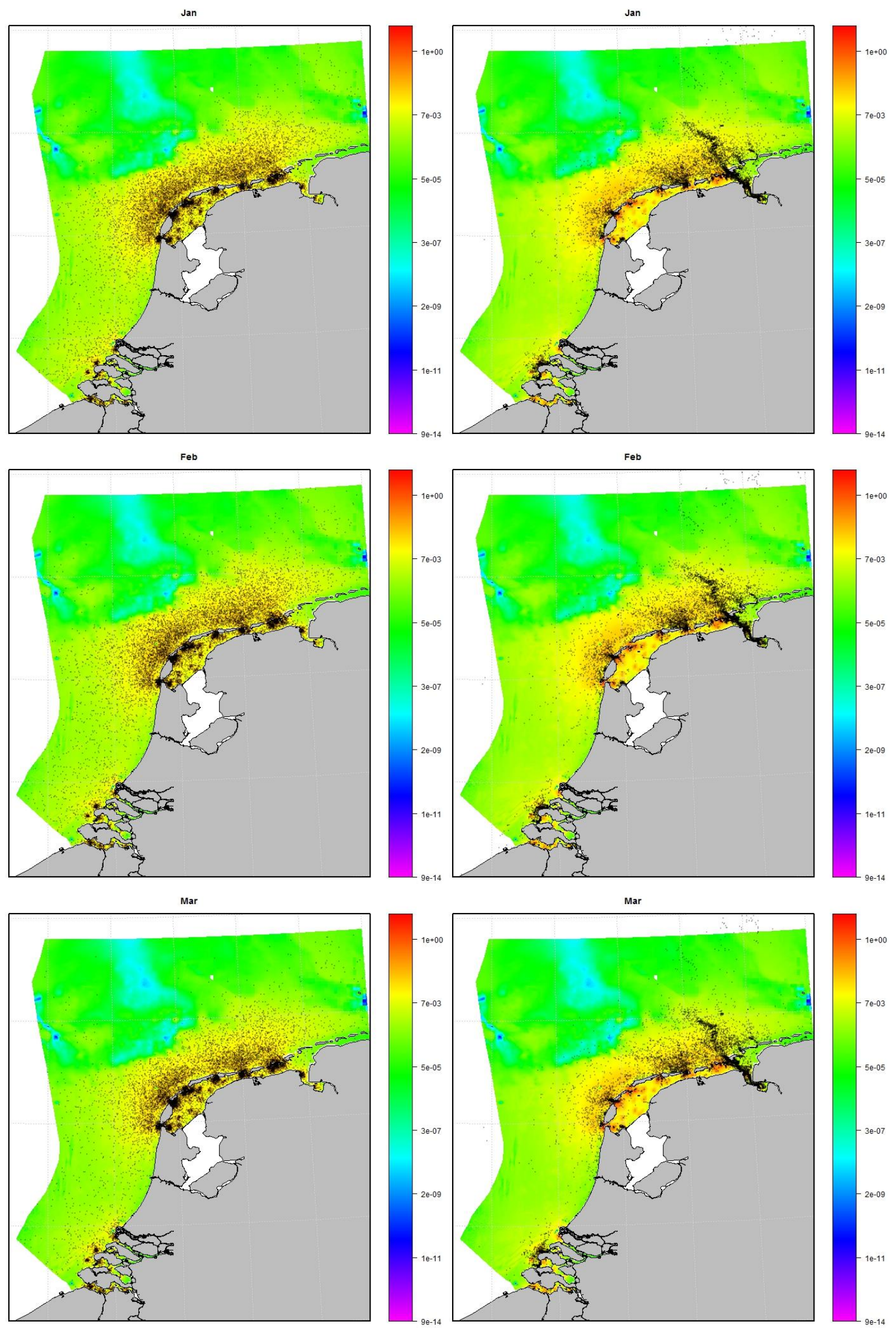


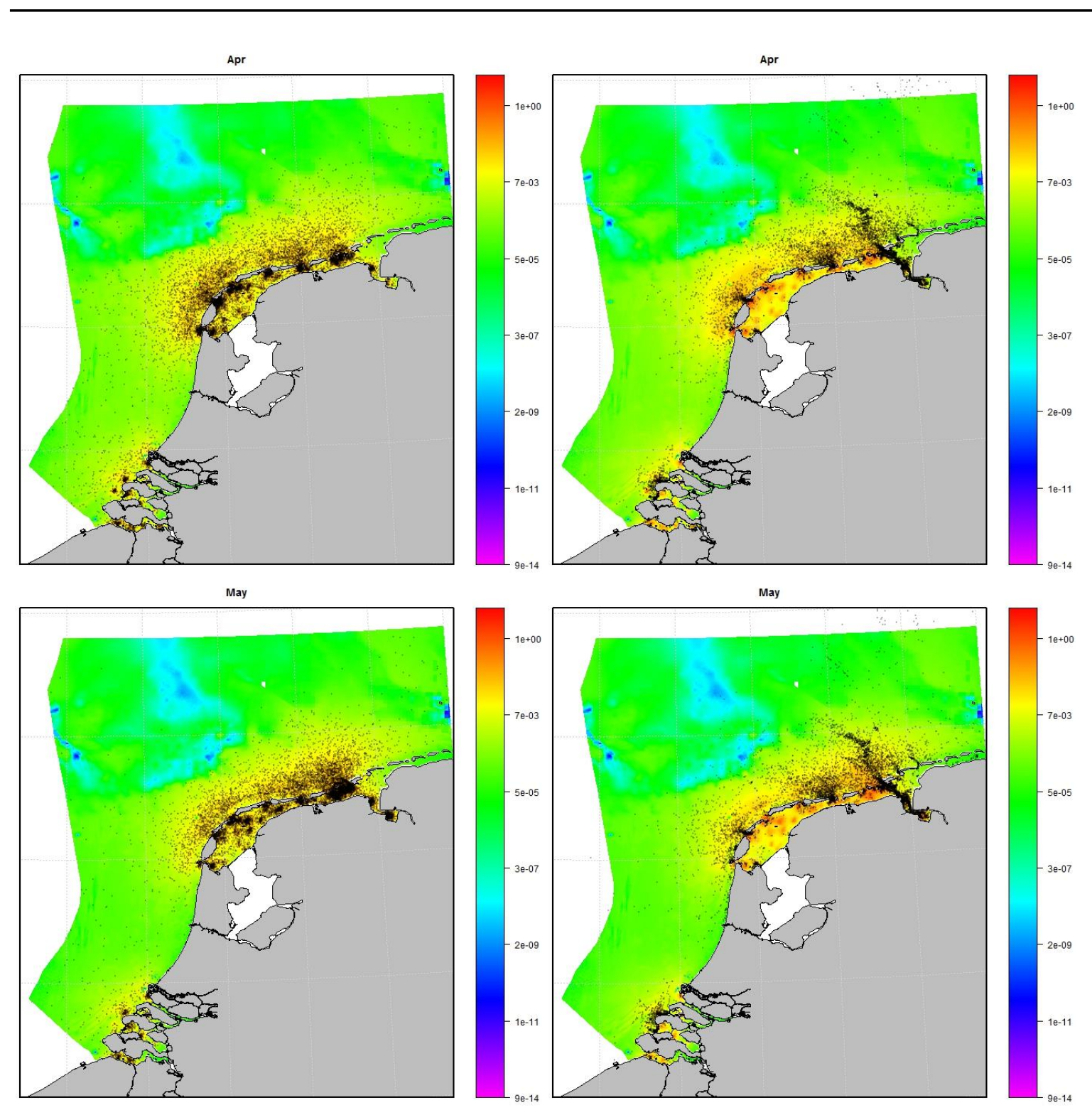



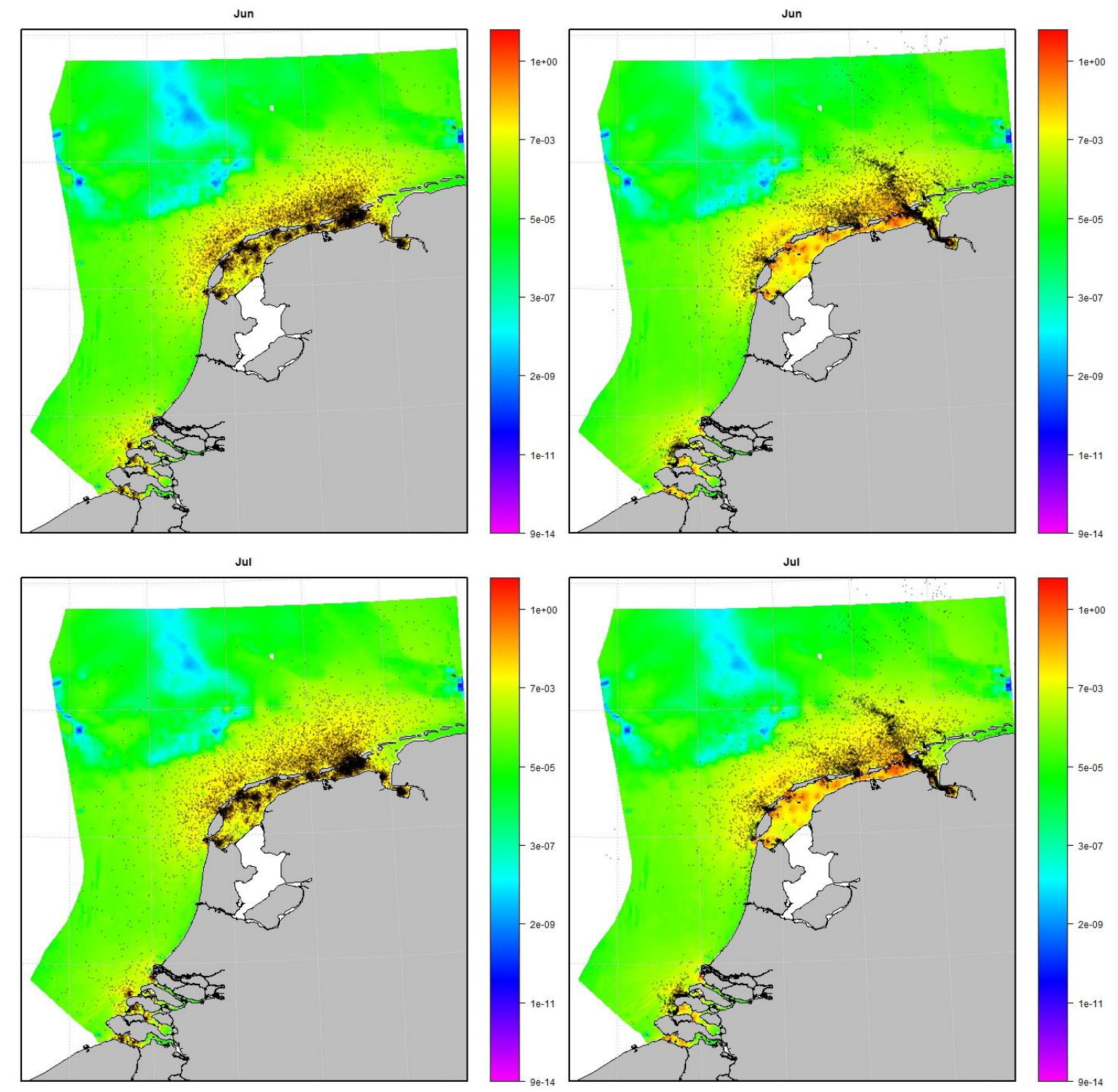
Wageningen Marine Research

T +31 (0)317480900

E: marine-research@wur.nl

www.wur.eu/marine-research

Visitors' address

- Ankerpark 271781 AG Den Helder

- Korringaweg 7, 4401 NT Yerseke

- Haringkade 1, 1976 CP IJmuiden
Wageningen Marine Research is the Netherlands research institute established to provide the scientific support that is essential for developing policies and innovation in respect of the marine environment, fishery activities, aquaculture and the maritime sector.

\section{Wageningen University \& Research:}

is specialised in the domain of healthy food and living environment.

\section{The Wageningen Marine Research vision}

'To explore the potential of marine nature to improve the quality of life'

\section{The Wageningen Marine Research mission}

- To conduct research with the aim of acquiring knowledge and offering advice on the sustainable management and use of marine and coastal areas.

- Wageningen Marine Research is an independent, leading scientific research institute

Wageningen Marine Research is part of the international knowledge organisation Wageningen UR (University \& Research centre). Within Wageningen UR, nine specialised research institutes of the Stichting Wageningen Research Foundation have joined forces with Wageningen University to help answer the most important questions in the domain of healthy food and living environment. 